\title{
Baccharis L. (Astereae): From Nova Scotia to Cape Horn
}

\author{
Gustavo Heiden' 1 [ \& J.Mauricio Bonifacino² (1) \\ ' Embrapa Clima Temperado, BR 392, km 78, Pelotas, RS 960 I0-97I, Brazil; gustavo.heiden@embrapa.br \\ 2 Laboratorio de Botánica, Facultad de Agronomía, Universidad de la República, Av. Garzón 780, Montevideo CP I2900, Uruguay; mbonifa@gmail.com
}

DOI: http://dx.doi.org/ | 0.53875/capitulum.0 I. I.02

Keywords: Asteraceae, Asteroideae, Baccharidinae, Compositae.

Baccharis L. (Astereae Cass.) occurs naturally in the Americas (Figure I), from Nova Scotia (B. halimifolia L.) to Cape Horn (B. magellanica Pers.) and from Northeastern Brazil Easternmost continental coast (B. cinerea DC.) to the USA Pacific Northwest coast (B. pilularis DC.), including the Caribbean, Galápagos, and Falkland/Malvinas islands. Within this area, 442 species are currently recognized and consist mainly of shrubs, though the genus also comprises varied habits, ranging from herbaceous plants to trees, including climbing shrubs Figure 2). These species occupy a wide variety of environments, ranging from seashores to the soaring heights of the Andes at $5,000 \mathrm{~m}$ a.s.l., and from tropical rainforests to dry deserts and the cold Patagonian steppes and tundra (Figure 3, Figure 4, Figure 5).

The genus is particularly diverse in South America (Figure I), with two main centers of both phylogenetic and species richness with high rates of endemism. The most important area, where the seven main phylogenetic lineages and almost half of the species are found, lies along the Eastern Brazilian highlands, from the table mountains of Chapada Diamantina in Bahia state, extending south to the Uruguayan Pampean hills. The second most speciose area, but with somewhat less phylogenetic representativeness, and also a high rate of endemism lies along the
Andes mountain range, especially between Bolivia and Peru. The spread to North America and the West Indies also resulted in important secondary centers of diversity and endemism north of the equator. In several open areas such as alpine vegetation, coastal scrubs, grasslands, Mediterranean vegetation, mountain slopes and savannas, species of Baccharis may be the dominant element of the vegetation defining the physiognomy of the natural landscape.

The generic name Baccharis has its origin in bakkaris, a designation applied by Dioscorides to the plant Cyclamen hederifolium Aiton (Primulaceae) with which an ointment for medicinal use was prepared (Quatrocchi, 1999). The resinous look of the plant may have reminded Linnaeus of the properties associated with the name present in Dioscorides' pharmacopeia, and although the plant referred to by the Greek botanist had nothing to do with these American plants, the reason was sufficient for the Swede to inscribe the name for posterity. In fact, many species of Baccharis are widely used as medicine to treat mainly liver diseases or digestive disorders. There are even different types of beverages that include compounds extracted from some Baccharis species. Conversely, some species are heavily toxic, especially for cattle (e.g. B. coridifolia DC. and 


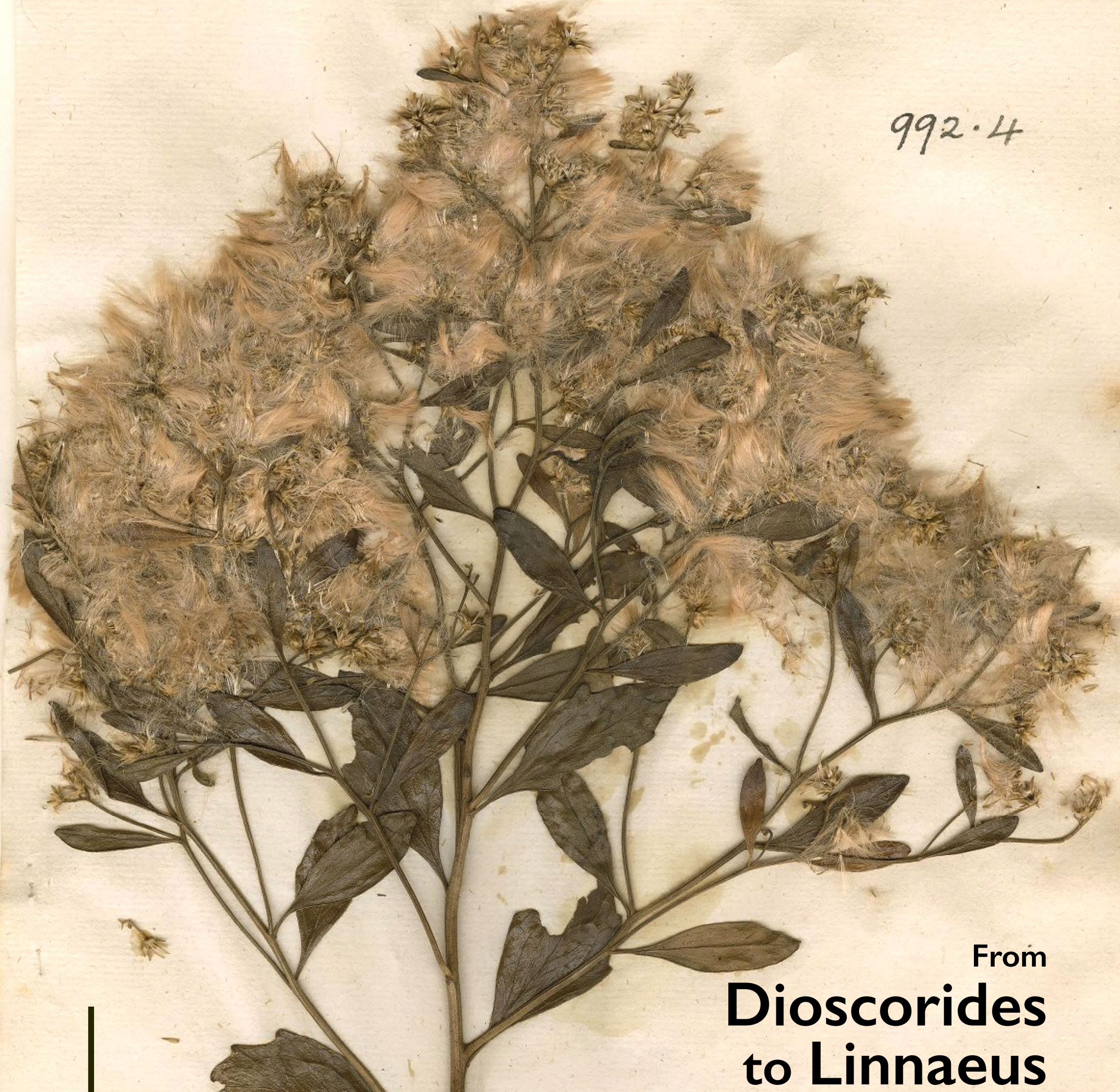

The name Baccharis was originally used $5 \mathrm{~cm}$

by Dioscorides to refer to a plant in his pharmacopeia. It was later taken by Linnaeus to refer to a plant also supposed to posses medicinal properties.

Baccharis halimifolia L., the type of the genus. Image courtesy and by permission of the Linnean Society of London. 


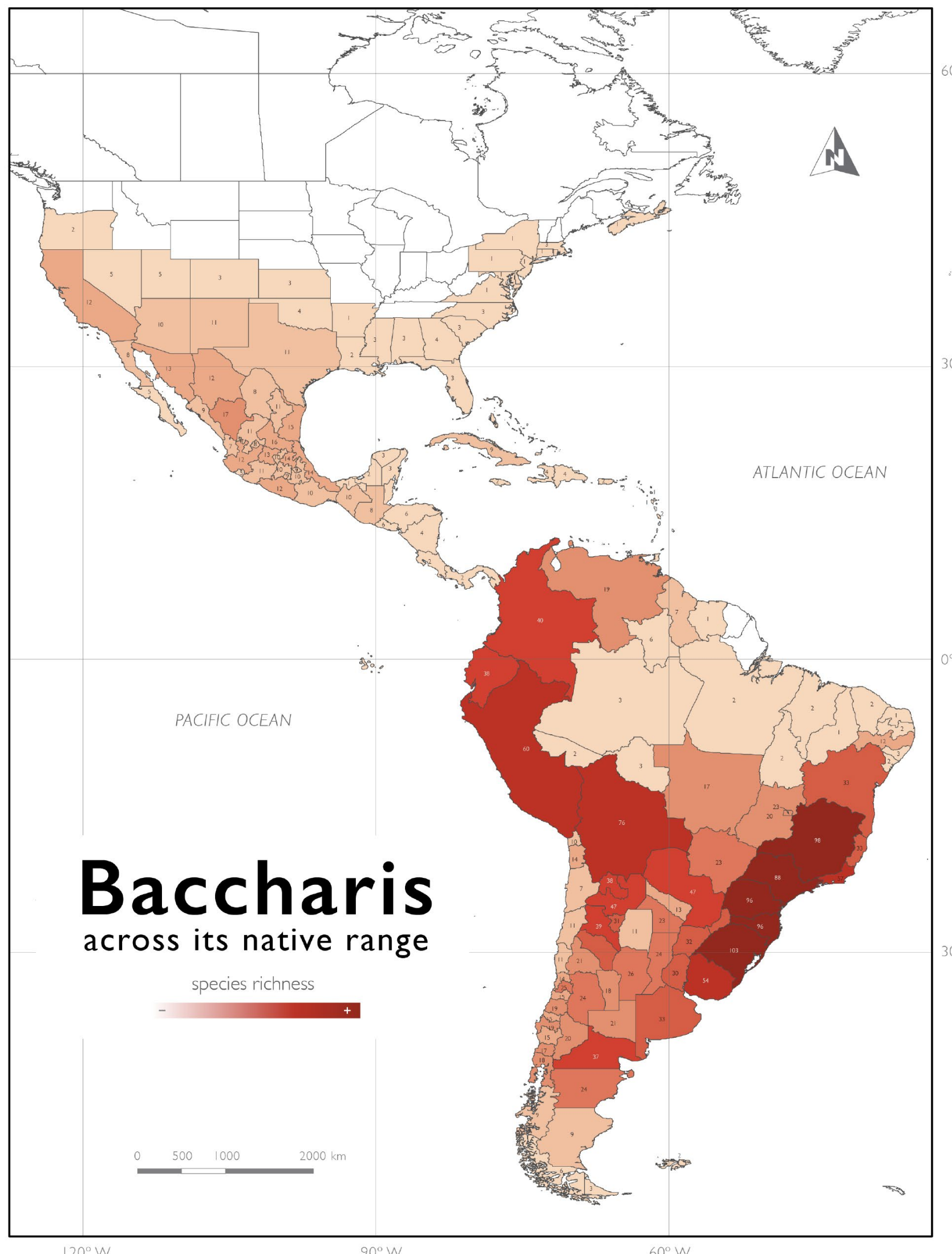

Figure I. Baccharis L. distribution and species richness by territory across its native range. Darker colors represent higher species richness. Blank areas have no species recorded so far. Number of species are given within political subdivions at TWG4. 


\section{Along the extensive}

\section{coastal mountain}

\section{range from Eastern}

\section{Brazil...}

Baccharis L. species usually constitute a characteristic and at times dominant element of the open and climax scrub vegetation. The rare Baccharis magnifica G. Heiden, Leoni \& J. Nakaj, stands out on the summit of Pico da Bandeira ( $2890 \mathrm{~m}$ - a.s. 1 ), the highest peak in the Eastern side of South America: Brazil atso stand's out accounting 185 species of Baccharis, 114 of them endemic, the highest number recorded for a single countery.

$\operatorname{lin}^{2}$

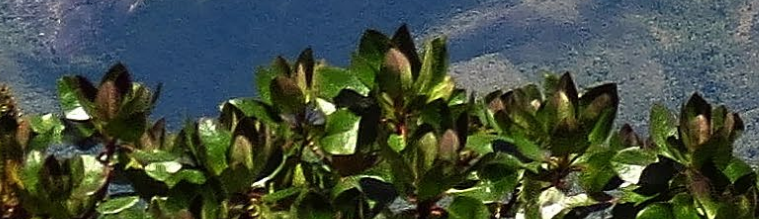

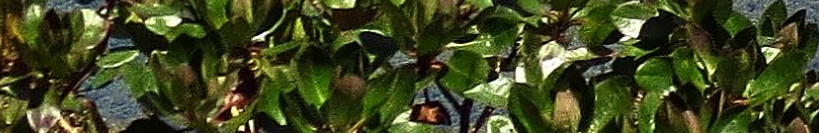

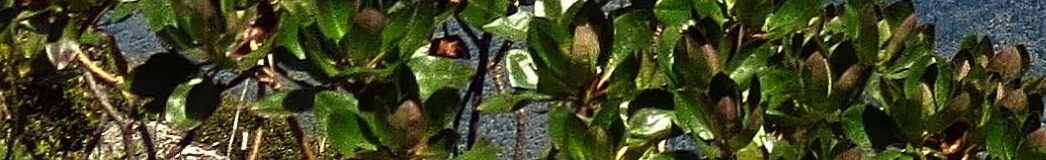

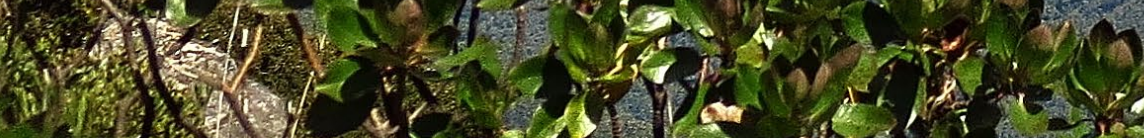
(ii) (2) 13 


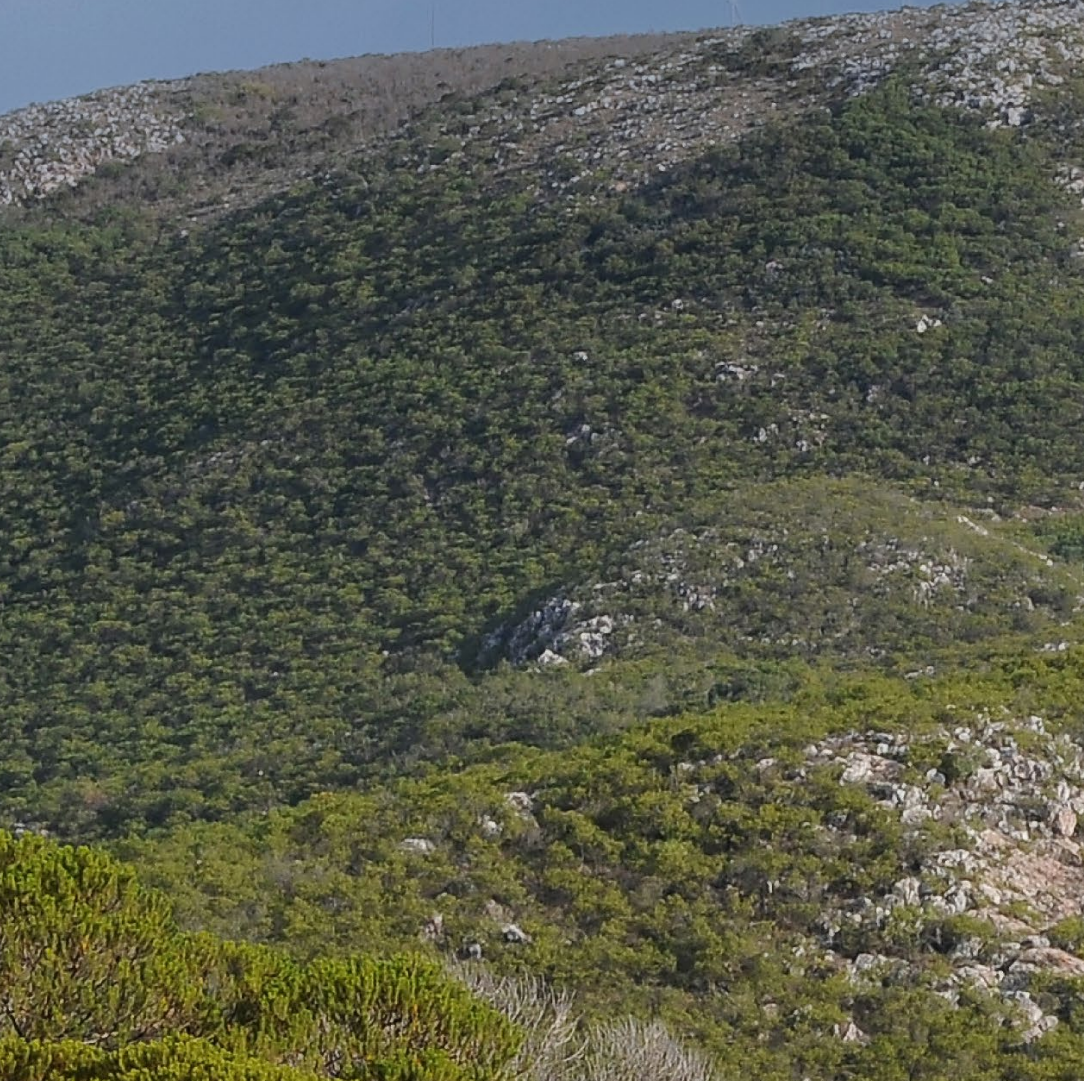

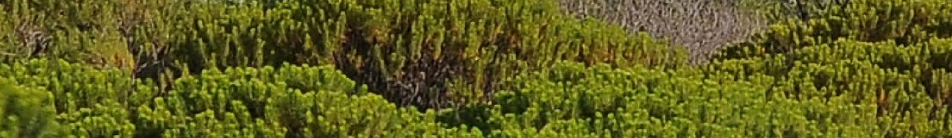

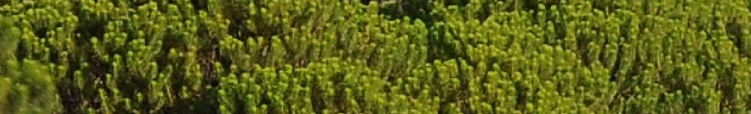

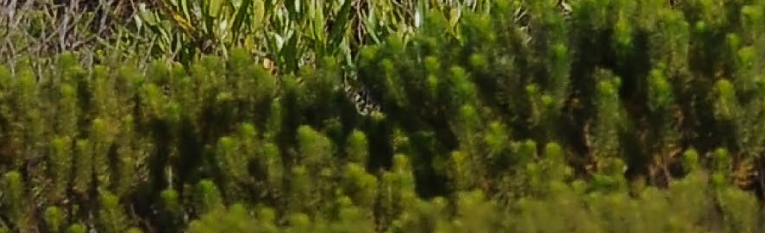

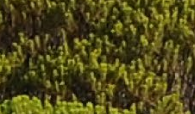

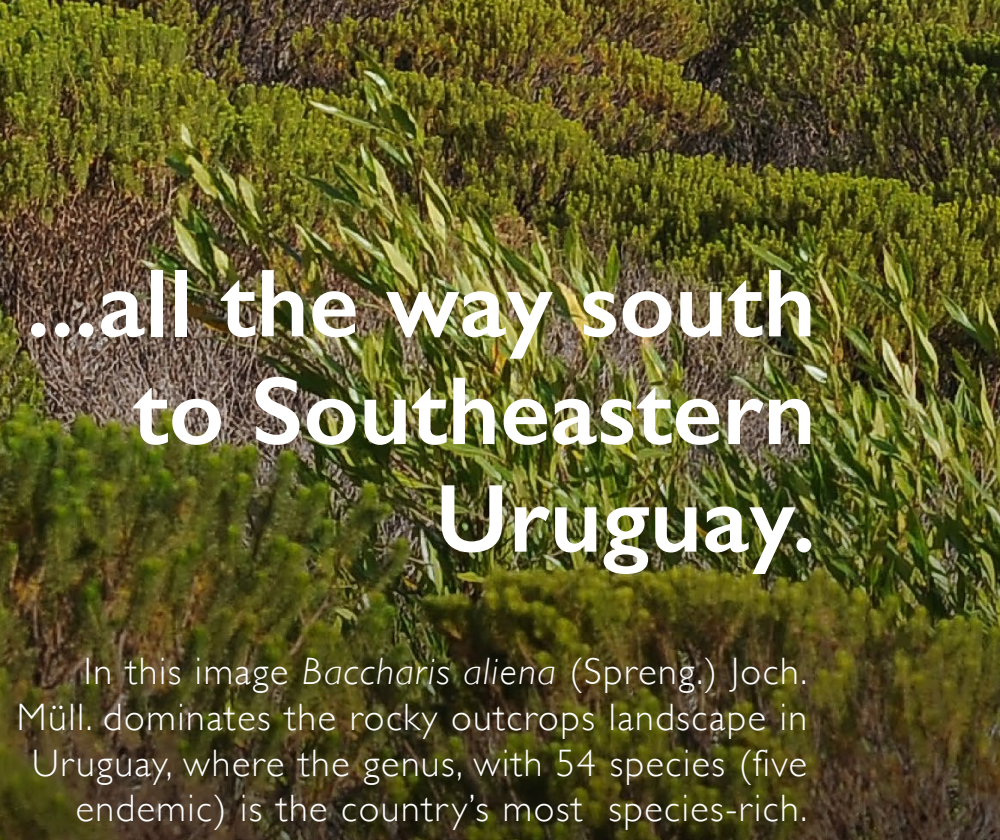



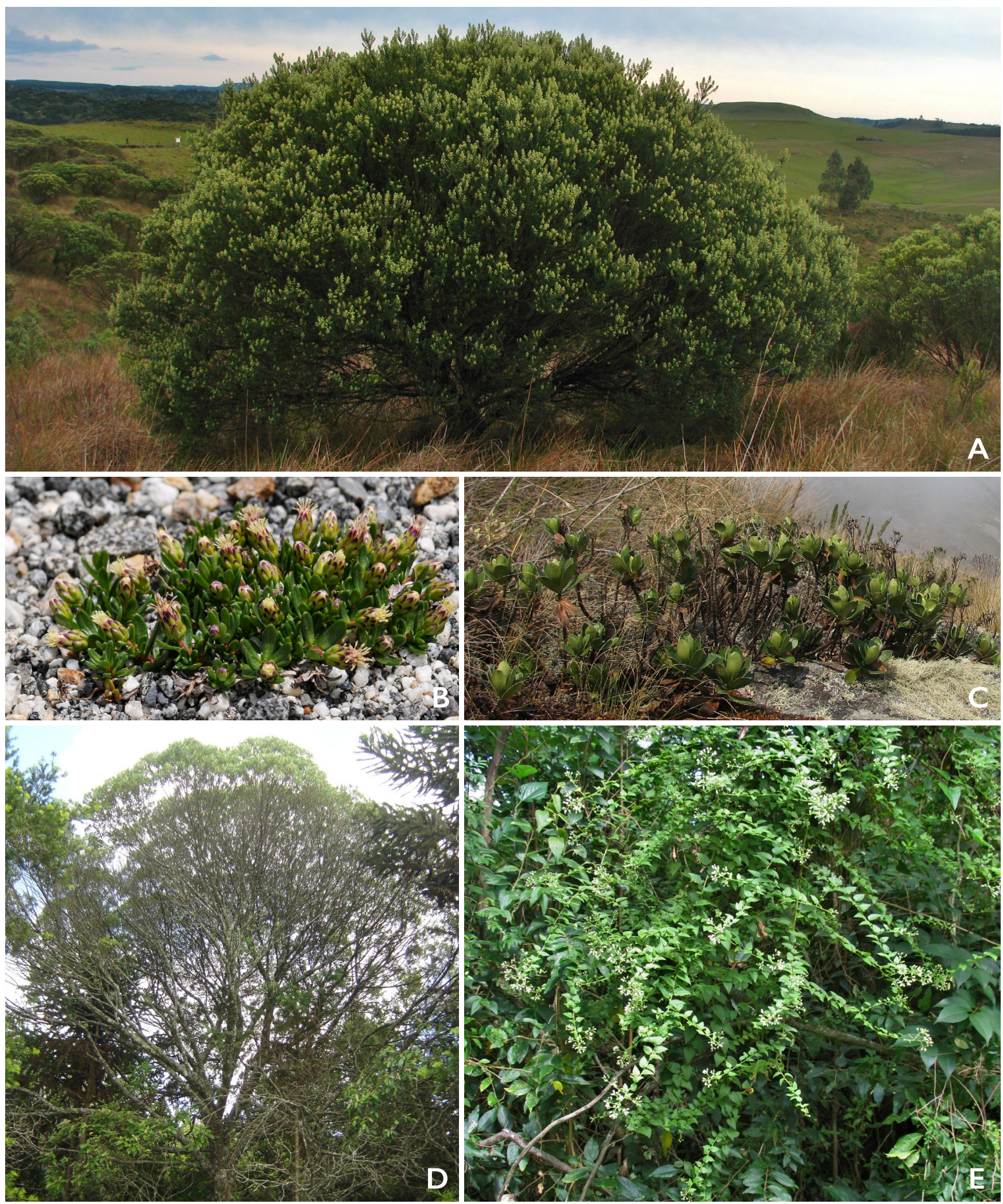

Figure 2. Habit diversity in Baccharis. A. Shrubby B. uncinella DC. from the subtropical highland grasslands, Lages, Santa Catarina, Brazil. B. Herbaceous B. nivalis (Wedd.) Sch.Bip. ex Phil. from the Patagonian Andes at Los Glaciares NP, Santa Cruz, Argentina. C. Subshrubby B. ciliata Gardner from the rock outcrops of Organ Mountains, Teresópolis, Rio de Janeiro, Brazil. D. Tree of B. Iongiattenuata A.S.Oliveira from seasonally semideciduous forests of Arroio do Padre, Rio Grande do Sul, Brazil. E. Scandent shrubby B. anomala DC. from the coastal scrubs of São Lourenço do Sul, Rio Grande do Sul, Brazil. Photos: A, C-E G. Heiden; B, M. Bonifacino. 
B. megapotamica Spreng.), likely due to the coevolution with endophytic fungi that synthetize macrocyclic trichothecenes (Jarvis et al., 1987, 1991). The genus is chemically as diverse as it is morphologically and ecologically, being widely explored for applications for industrial and pharmaceutical purposes, including drug discovery for cancer and noxious viral and bacterial diseases (Campos et al., 2016). Baccharis has also been explored in search of cultivars for ornamental purposes (for example B. halimifolia L., B. pilularis DC. and B. sarothroides A. Gray). Some species also cause negative economic impacts as weeds (B. articulata (Lam.) Pers., B. coridifolia DC., B. dracunculifolia DC., B. halimifolia L., B. neglecta Britton, B. punctulata DC., and B. trimera (Less.) DC.), phreatophytes (B. salicifolia (Ruiz \& Pav.) Pers.) and pyrophytes (B. pilularis DC., B. sarothroides A.Gray) (Boldt, 1989; Thompson et al., 1995).

Being such an abundant genus of plants and with such a wide distribution, it is not surprising that many of the members of the pantheon of researchers of the Compositae have proposed generic segregates or coined diverse and frequently discordant proposals of infrageneric classifications. Although the concept of the genus has varied throughout history (see Heiden et al. 2019), mainly because several authors have focused mostly on the reproductive behavior of the whole plant or species, rather than on the
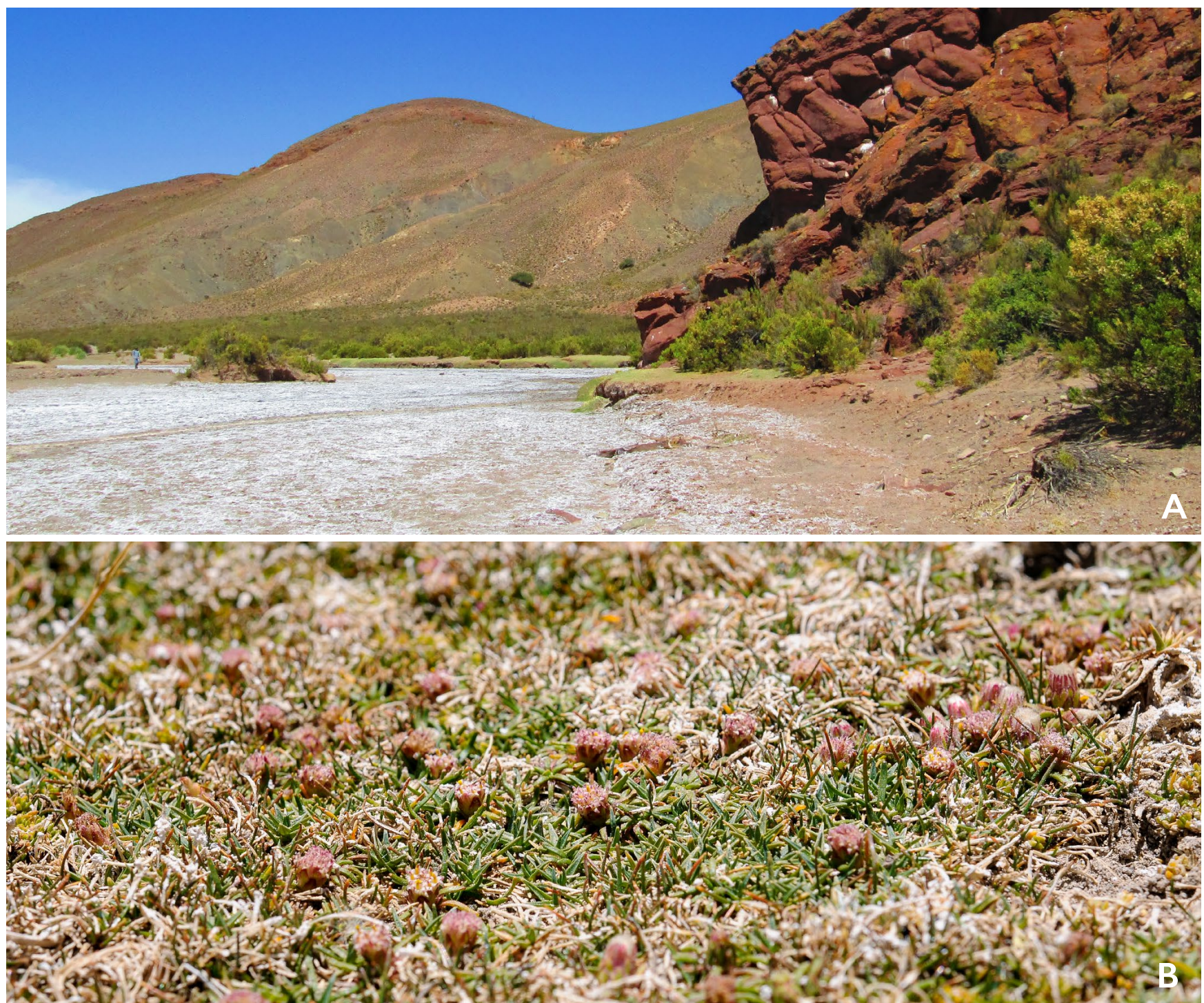

Figure 3. A. Salt streams margins and salt flats are the extreme habitat of B. acaulis (Wedd. ex R.E. Fr.) Cabrera, noticeable as the light green moss-like vegetation covering the margins of this seasonal water course at 3,750 m a.s.l., Ticatica, Potosí, Bolivia. B. B. acaulis moss-like herbaceous appearance, with rosulate and linear leaves above ground, hides a buried rhizomatous subshrub with underground leaves reduced to scales. Photos: A. G. Heiden; B. M. Bonifacino. 

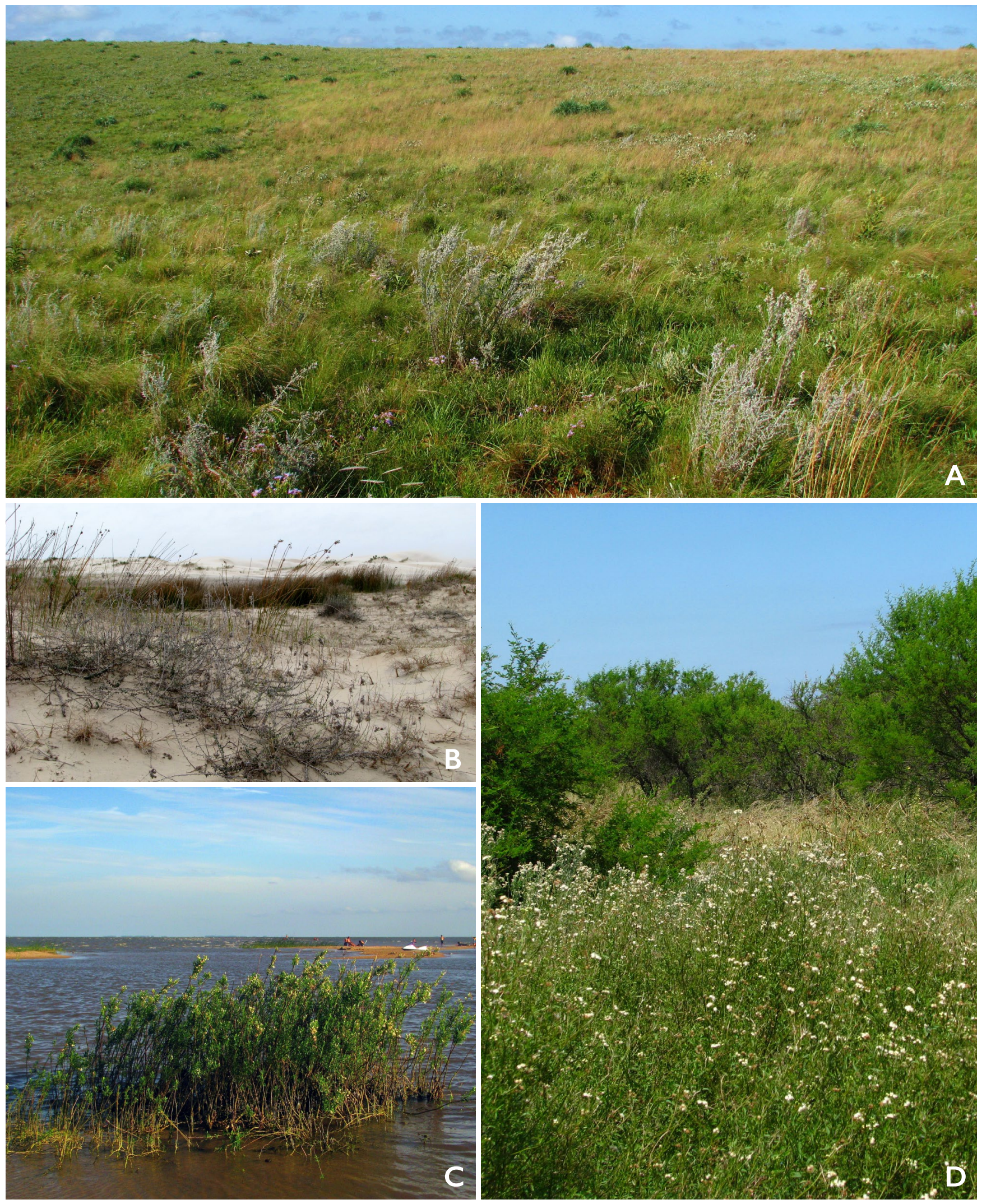

Figure 4. Baccharis habitats accros biomes. A. The greyish subshrubby B. albilanosa A.S. Oliveira \& Deble in the pampas of Manoel

Viana, RS, Brazil. B. The greysh decumbent subshrubby B. gnaphalioides Spreng. on coastal dunes at Tavares, RS, Brazil. C. Shrubby B. arenaria Baker in coastal wetlands at Lago Merín, Cerro Largo, Uruguay. D. Shrubs of B. pingraea DC. in Chacoan savanna at Barra do Quaraí, RS, Brazil. Photos: G. Heiden. 

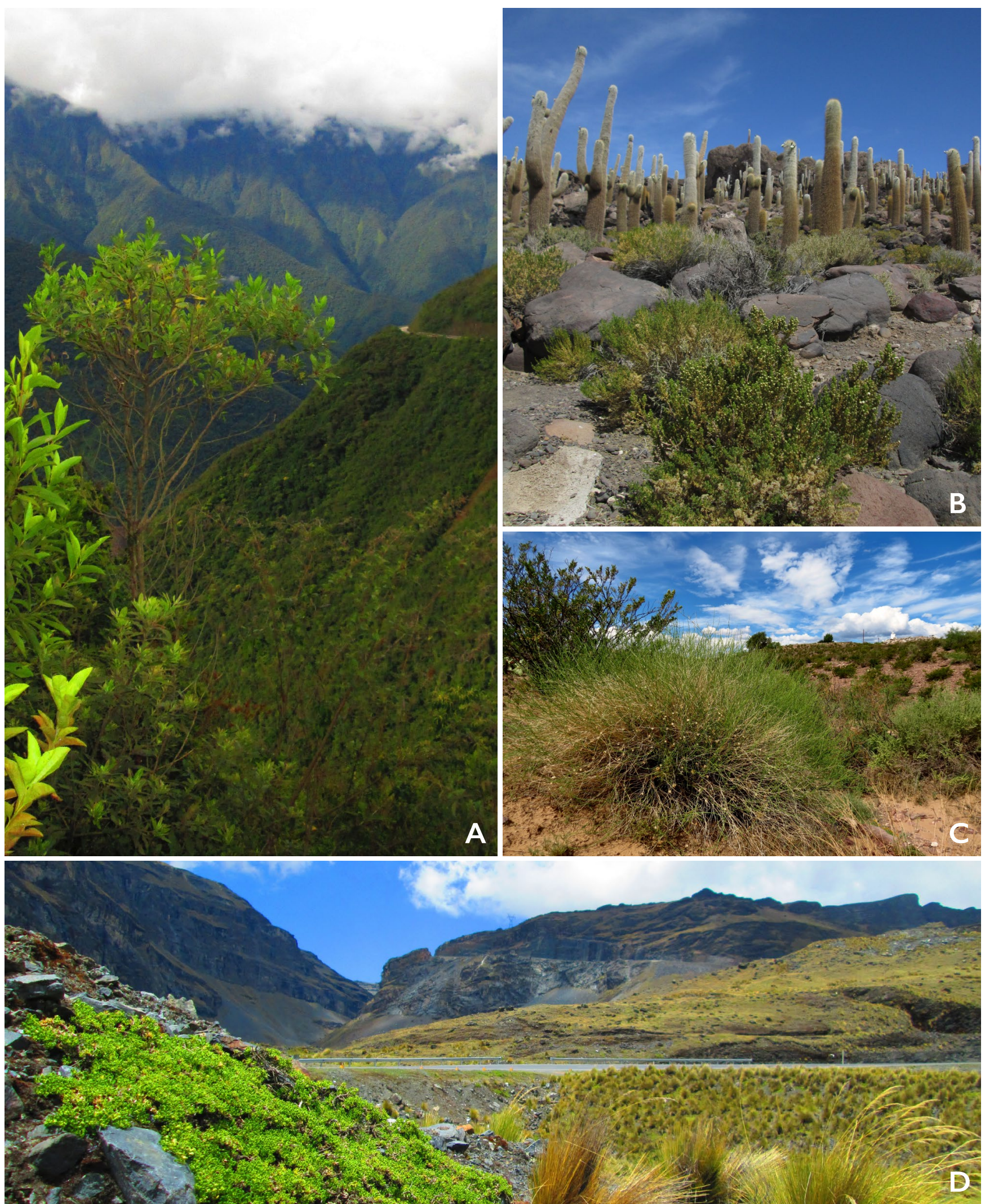

Figure 5. Baccharis habitats across biomes (cont.). A. Shrubby B. nitida (Ruiz \& Pav.) Pers. on mountain slopes of the Yungas rainforests from Coroico, Bolivia. B. Shrubs of B. boliviensis (Wedd.) Cabrera in the semidesert Puna vegetation in Isla Incahuasi, Salar de Uyuni, Oruro, Bolivia. C. Subshrubs of B. wrightii A. Gray in the Chihuahuan Desert, Valencia, New Mexico, USA. D. The creeping subshrub B. caespitosa (Ruiz \& Pav.) Pers. covering exposed rolled rocks at $4500 \mathrm{~m}$ a.s.l. along the Carretera de la Muerte, La Paz, Bolivia. Photos: G. Heiden. 
individualized form and function of the reproductive structures, the genus circumscription is currently back to its original broader conception, though with a twist. Baccharis is now defined on the basis of the presence and predominance of functionally staminate monoclinous florets and diclinous pistillate florets, generally arranged in distinct mostly homogamous capitula usually located in distinct plants (Figure 7, Figure 8), e.g. functionally dioecious plants, with the exception of B. monoica G.L.Nesom, which has functionally staminate and pistillate capitula in the same specimen. Capitula bearing fully functional monoclinous florets allegedly could occur in one species (e.g. B. pohlii (Baker) Deble \& A.S.Oliveira); however, their peculiar biology in the context of the genus characteristics should be further investigated with field studies. The scattered and accidental occurrence of a few monoclinous central or marginal florets is not rare in functionally pistillate capitula of several species from unrelated sections and subgenera. Similarly, sterile pistillate marginal florets can sometimes occur in functionally staminate capitula across several unrelated lineages. Further adding to this floral diversity, some clades consistently have heterogamous capitula (e.g., the sister species B. breviseta DC. and B. vulneraria Baker; the three species belonging to Baccharis sect. Heterothalamus (Less.) Giuliano. Species or individuals that do not conform to this rigid combination of functionally staminate/pistillate florets and arrangement of capitula across plants can be considered as the queer result of the evolutionary exploration of a genus willing to be bold, as depicted in Figure 9. As in nature, success and resilience in Baccharis is determined by diversity.

Most Baccharis species present an unique arrangement of fused trichomes sharing the same single basal cell. These fused trichomes, referred to as "tufted indument" (Figure 6) are composed of uniseriate and biseriate glandular types and were first described by Volkens (1890). The trichomes making up the tufted indumentum are located in micro depressions along the surface of the leaves, and exudate a resin layer that confer the distinctively oily and bright appearance of many species. These tufted vestiture has been considered a probable synapomorphy of the whole genus (Müller 2006). However, it is absent in Baccharis subgen. Tarchonanthoides Heering, the first diverging lineage (Heiden et al.
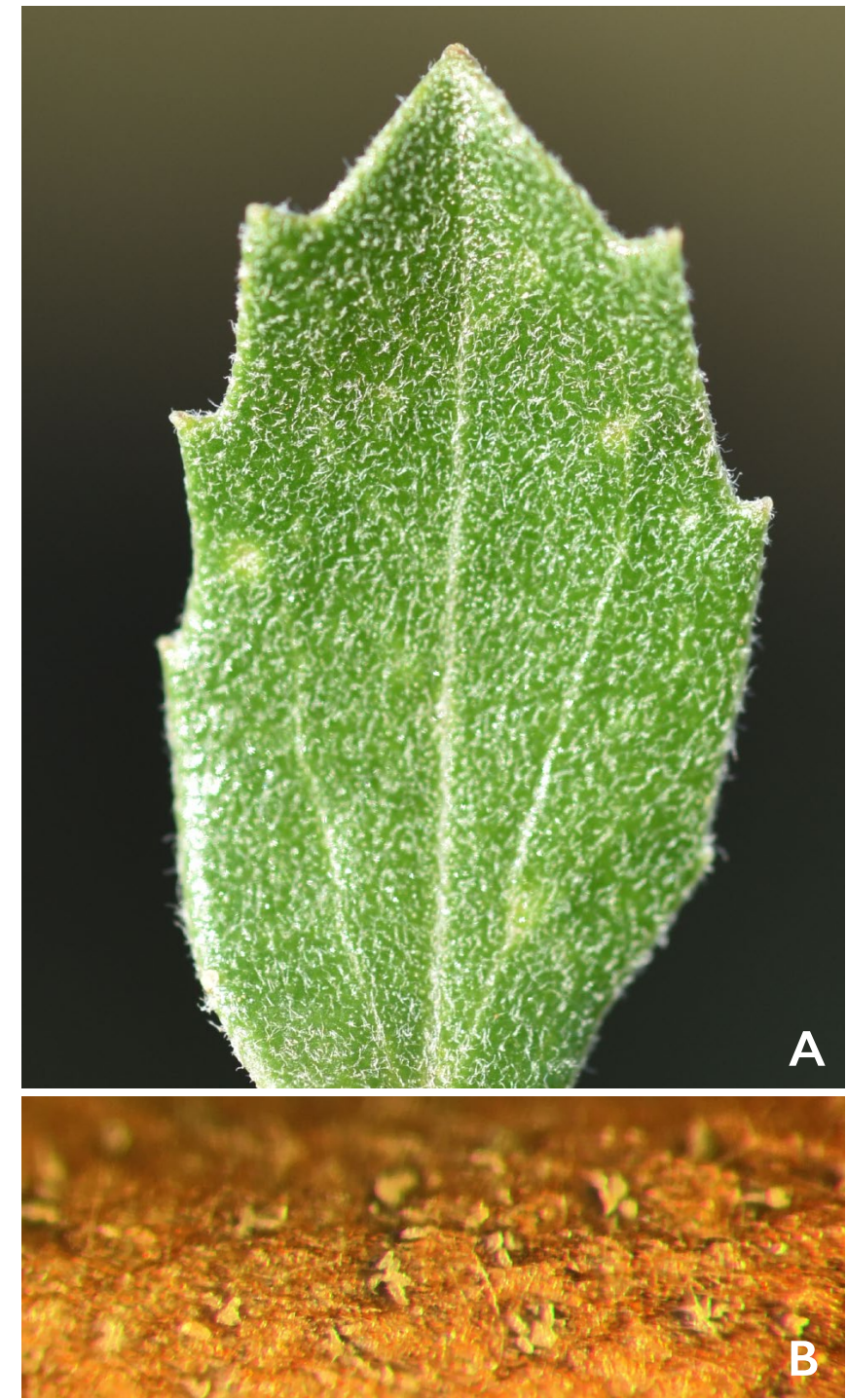

Figure 6. Indument in Baccharis. A. Detail of young leaf of Baccharis dracunculilfolia, notice that there is a conspicuous indument of uniseriate trichomes (with branched terminal cell) easily visible at naked eye shadowing an almost inconspicuous microindument of uniseriate and biseriate glandular trichomes, some of them free, while the majority are packed in clusters with a single adjoining basal cell and placed in minute cavities conforming the so-called tufted indument characteristic of the vast majority of the genus. B. Close up of the "punctateglandular" tufted microindument. Photos: M. Bonifacino.

2019), demonstrating that this novel trait appeared later in the genus, being present as a synapomorphy of the subsequent diverging lineages, although with complete reversions in Baccharis subgen. Coridifoliae (DC.) G.Heiden and in some sections or species of B. subgen. Heterothalamus (Less.) G.Heiden, B. subgen. Molina (Pers.) Heering and B. subgen. Baccharis. 


\section{CAPITULUM ORGANIZATION}

distribution of monoclinous and diclinous florets across heads \& plants

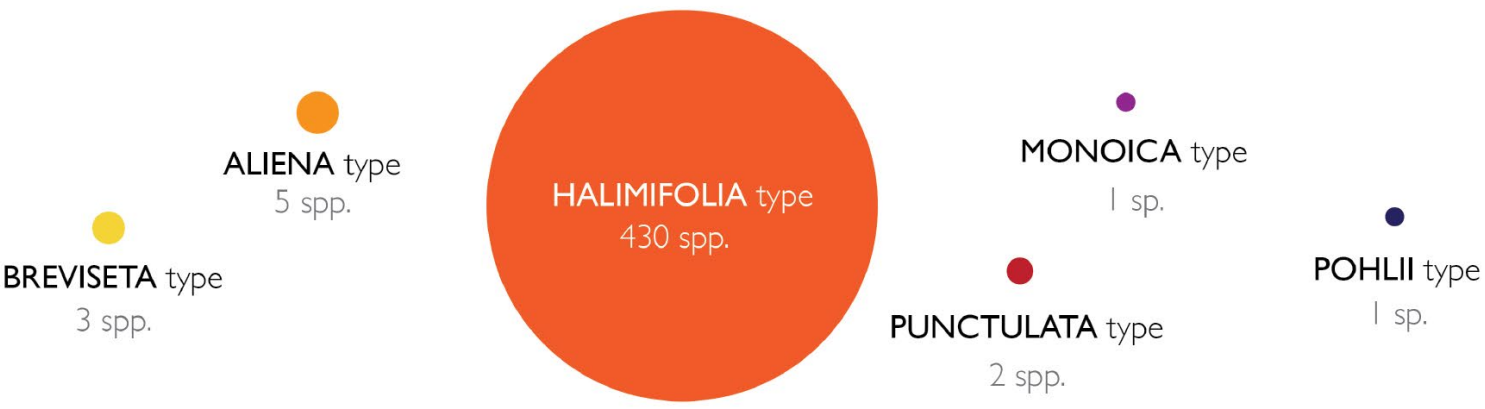

FLORETS in BACCHARIS
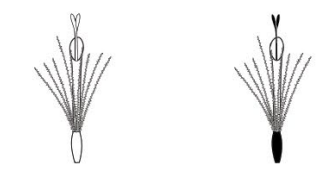

Diclinous
(Pistillate)

orolla short-rayed;

sterile ginoecium

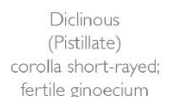

fertile ginoecium

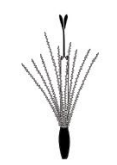

Diclinous
(Pistillate),

corolla filiform,

fertile ginoecium

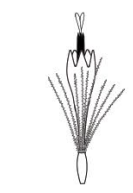

Monoclinous

(Staminate),

corolla tubulose,

fertile
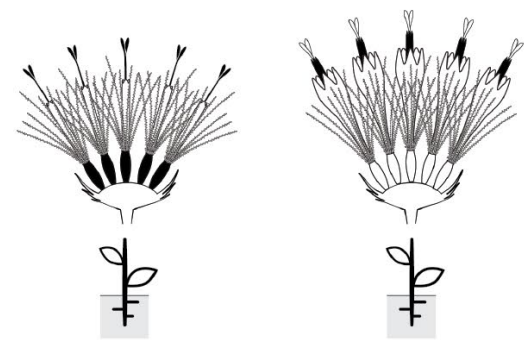

\&oth androecium
HALIMIFOLIA type Two types of homogamous capitula, each in different
individuals. Capitula with either monoclinous or pistillate florets

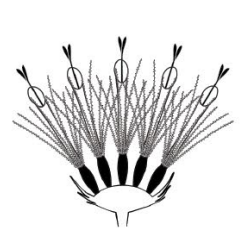

of

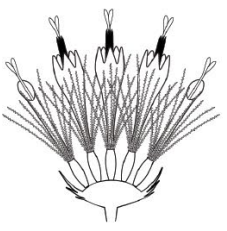

of

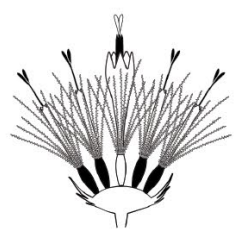

of

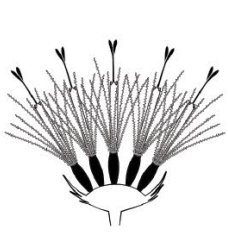

o

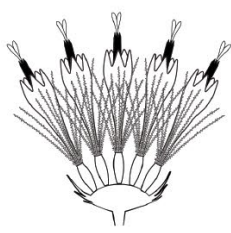

of

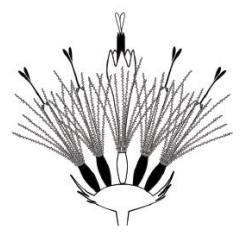

of

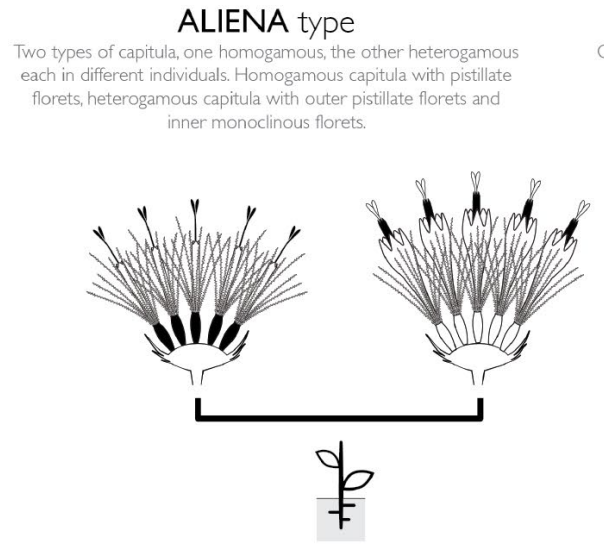

MONOICA type

homogamous capitula in the same indiv

\section{BREVISETA type \\ type of capitulum, heterogamous; pistillate outer florets and}

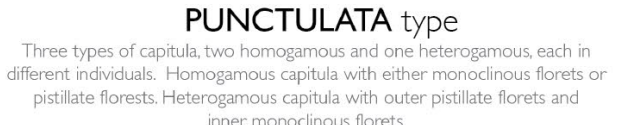
inner monoclinous florets.
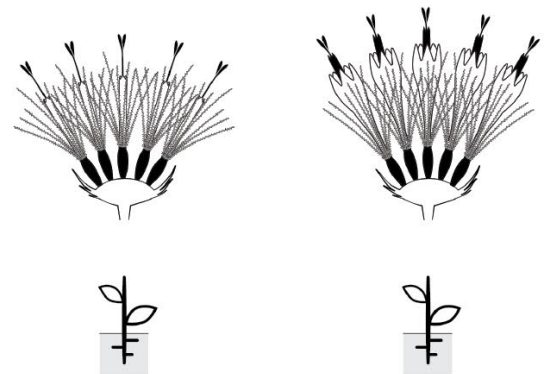

of

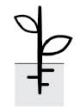

POHLII type

Figure 7. Capitulum organization infographic, showing the distribution of florets in capitula and across plants in Baccharis (circle size is proportional to number of species). Notice the dominance of the characteristic Halimifolia type, present in over $97 \%$ of the species. 
Homogamous capitulum with monoclinous staminate florets
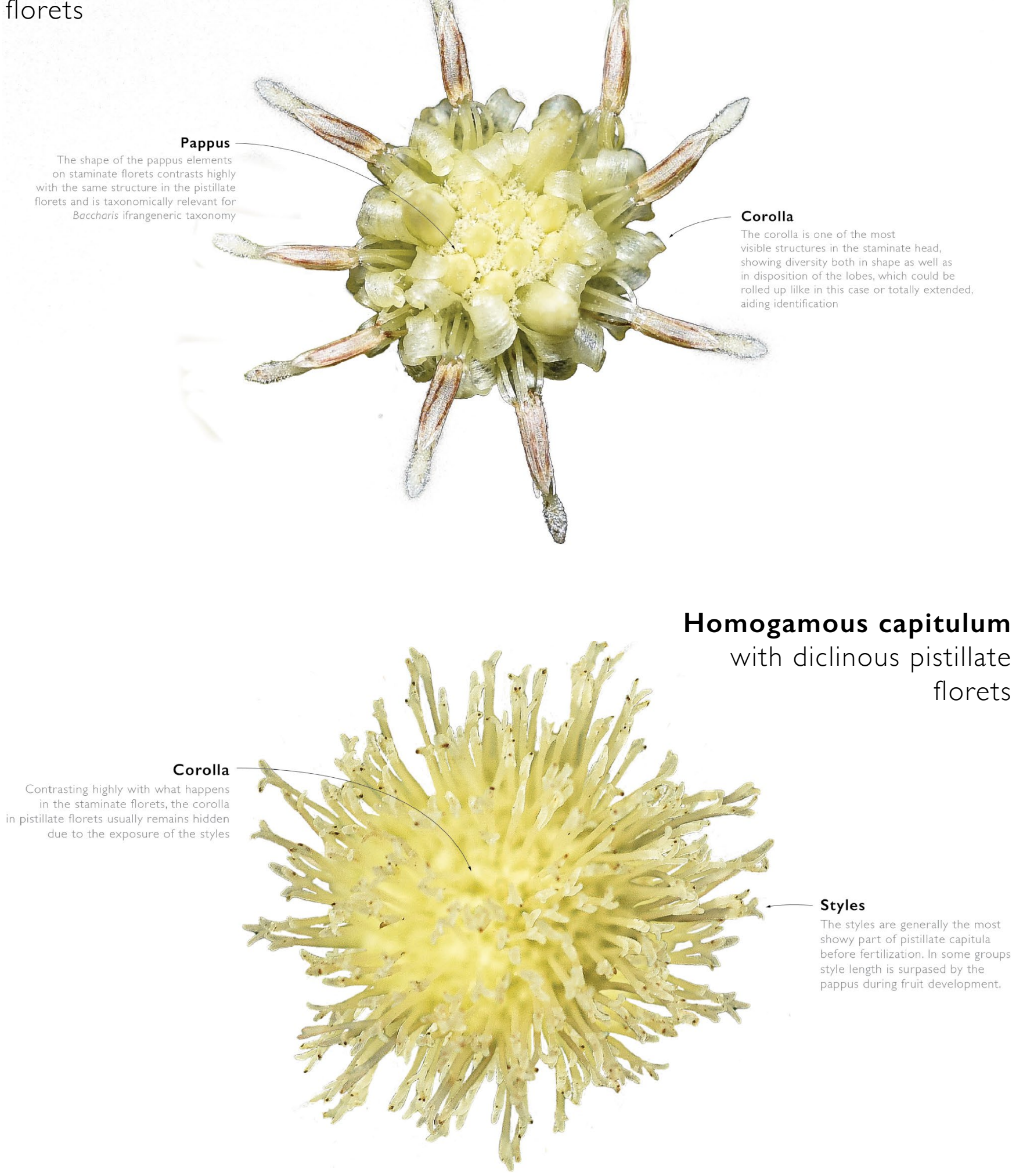

Figure 8. Superior view of two homogamous capitula conforming the Halimifolia type, the commonest arrangement found in $97 \%$ of the species of Baccharis. Photos: M. Bonifacino. 


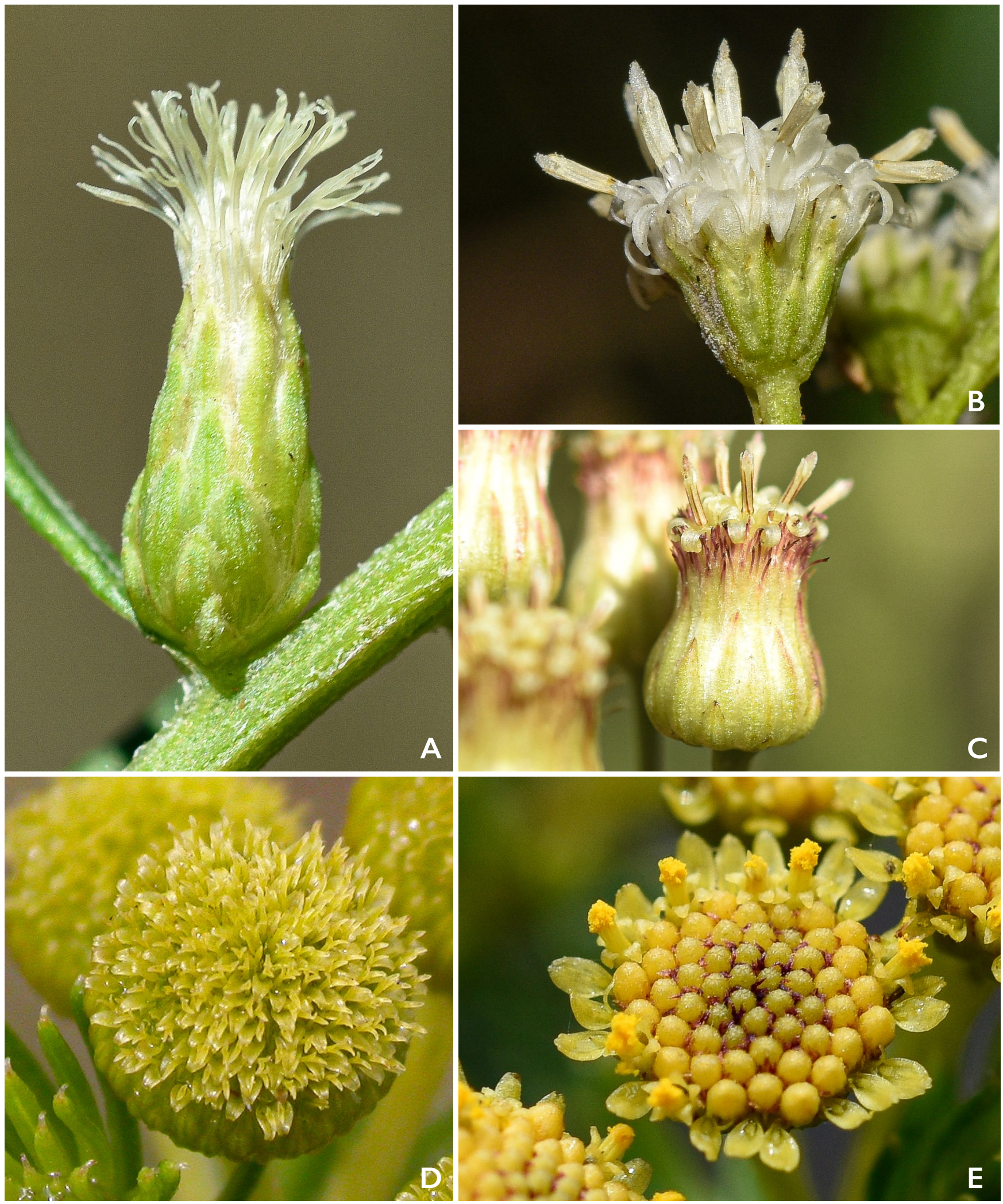

Figure 9. Examples of main types of capitula in Baccharis. A. Homogamous capitulum with pistillate florets with filiform corollas (B. megapotamica Spreng.). B. Homogamous capitulum with staminate florets with tubulose corollas (B. pingraea DC.). C. Heterogamous capitulum with outer pistillate florets with fililform corollas and inner monoclinous florets with tubulose corollas (B. vulneraria Baker). D. Homogamous capitulum with pistillate forets with short-rayed corollas (B. aliena (Spreng.) Joch.Müll.). E. Heterogamous capitulum with outer pistillate florets with short-rayed corollas and inner monoclinous florets with tubulose corollas (B. aliena). Photos: M. Bonifacino. 
It is something remarkable and curious to point out that, unlike what occurs in the style of monoclinous florets of most Astereae, in Baccharis, the two marginal stigmatic bands are absent, communicating the exclusive staminate functionality in a formidable way and reassuring the irreplaceable function of the pistilodium for the secondary pollen exposure characteristic of the family. Another remarkably distinctive trait that we can also link to the functionality of the florets is the shape of the pappus elements. In monoclinous florets, the pappus elements have a frizzy appearance and usually have longer ornamentations and an apex broader than those usually observed in the pistillate florets, where the elements are straight, without the frizz and commonly not or only slightly broadened towards the apex (Figure I I).

It is usual to feel somewhat intimidated or lost when faced with having to identify a specimen belonging in a genus with more than four hundred species that has not been approached taxonomically as a whole since Candolle (1836). The problem thickens as recent floras with treatments for Baccharis are lacking for most of the areas where it occurs. The task of identifying an unknown Baccharis specimen

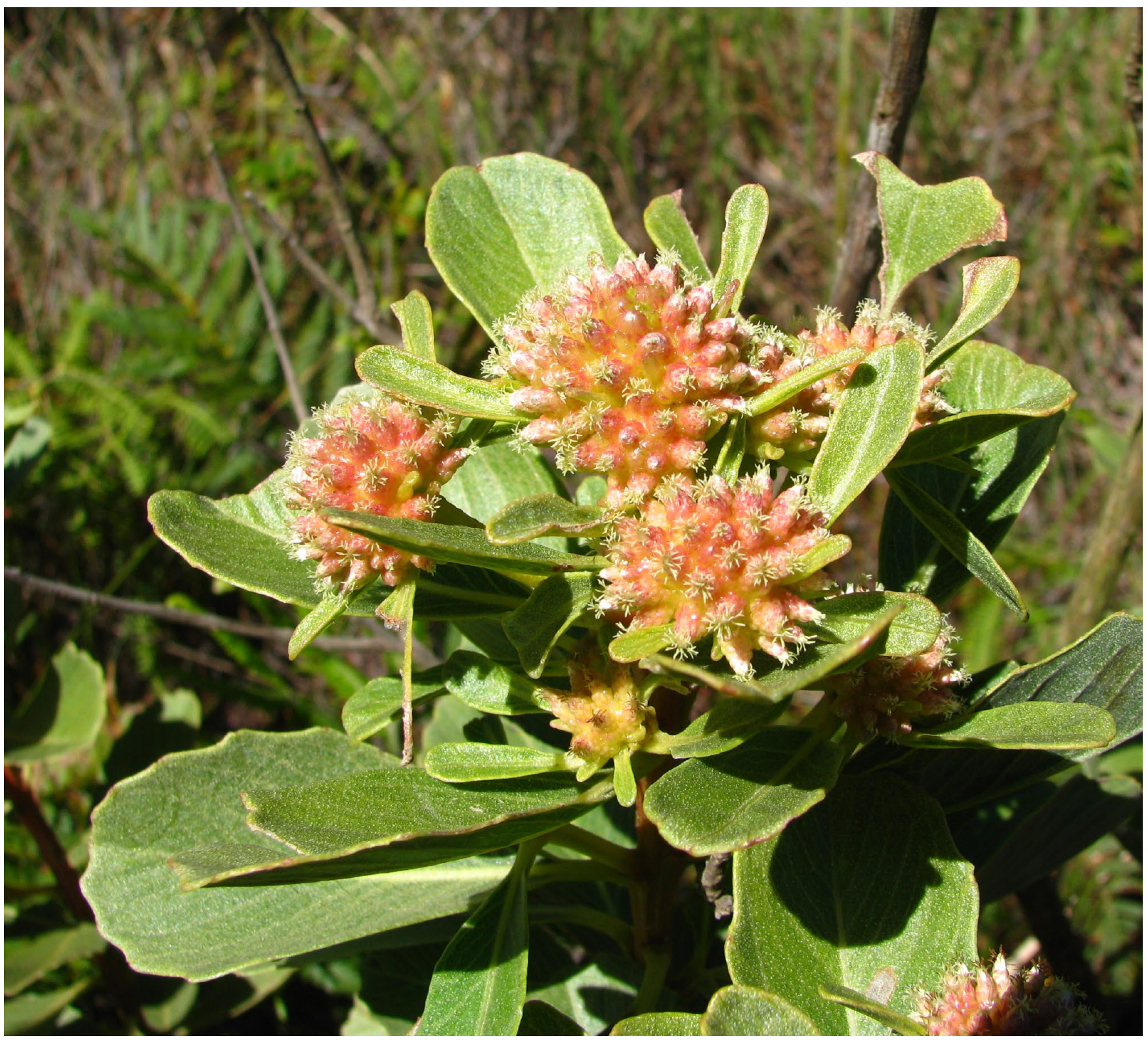

Figure I0. An individual with homogamous capitula containing pistillate florets of Baccharis platypoda DC. showing the remarkable capitulescence composed by secondary capitula. This arrangement is an unusual trait within the genus found in a few not so closely related species of Baccharis subgen. Baccharis. Photo: G. Heiden. 
is also challenging, especially to those unfamiliar with the group, because some easily accessible macrocharacters such as habit, apterous or winged stems, leaf shape, capitula arrangement (Figure 10), are frequently misleading due to convergence or homoplasy. To overcome these barriers, one needs to know where to look at and what to look for as some reproductive traits (Figure $\mathrm{I} \mathrm{I}$ ) and microcharacters (Table I), when combined, are useful to restrict the search to the level of subgenera and sections. Indeed, just by observing the indumentum, the shape of the pappus elements and style apex in monoclinous florets, the structure and development of pappus and type of corolla apex in pistillate florets and the number of ribs in the cypselae (Figure 14) gives one ammunition to greatly reduce a group of hundreds of species to just a few or, at most, a few dozen species (Figure 13). Conversely, the habit, the presence or absence of winged stems, the shape of leaves and the types of capitulescences (Figure 10) present a formidable variation that assists in the identification of species within infrageneric groups, although it is often of little help for defining subgenera or sections.

Notwithstanding the current sampling effort, including 35 out of 47 sections and more than half of the species, a thorough phylogenetic sampling encompasing representatives of all sections is still lacking. This is particularly important for the sections of unknown relationships within Baccharis subgen. Baccharis (B. sect. Discolores DC., B. sect. Divaricatae Giuliano, B. sect. Frenguellianae Giuliano, and B. sect. Pedicellatae Heering) and Baccharis subgen. Molina (B. sect. Albidae Giuliano, B. sect. Aristidentes G.L.Nesom, B. sect. Gladiatae Cuatrec., B. sect. Pinnatae Cuatrec., B. sect. Punctatae Giuliano \& G.L.Nesom, B. sect. Rodriguezianae Giuliano, B. sect. Tenellae Giuliano, and B. sect. Tubulatae Cuatrec.), as well as the unplaced species at sectional level within these same subgenera (16 in Baccharis subgen. Baccharis and 17 in B. subgen. Molina). In addition to the gaps in phylogenetic representativeness, there still remain important geographical sampling voids, particularly for species endemic to Mexico, Peru and Venezuela.

The classification published by Heiden at al. (2019) paved the way to a better understanding of this truly remarkable group. However, some of the clades retrieved still lack morphological backing (Figure 13), and the answer to this may be hidden in both microcharacters and those derived from chemical markers. The genus is currently divided into seven subgenera and 47 sections (Figure 12). We provide below a summary of this subgeneric classification, with brief descriptions of each subgenus and information on its conformation in terms of the number of sections and constituent species. For sections, a table with key traits is provided (more detailed information on the sections and species assigned to each subgenus can be found in Heiden et al. 2019).

\section{TAXONOMIC SYNOPSIS}

Baccharis Sp. Pl.: 860. I 753. Type: Baccharis halimifolia L., typ. cons.

Seven subgenera, 47 sections and 442 species (and counting!).

Baccharis subgen. Tarchonanthoides Heering, Jahrb. Hamburg. Wiss. Anst. 2 I (3): 26, 1904.

( as "Tarchonantoides").

Type: Baccharis tarchonanthoides DC.

Trees, shrubs, or subshrubs. Indument not tufted, mostly of filiform trichomes. Stems apterous. Leaves developed. Capitula homogamous, structure and arrangement of Halimifolia type. Receptacle of pistillate capitula epaleate. Staminate florets with pappus elements linear and scabrid towards the apex, pistillodium apex linear-oblong. Pistillate florets with corollas tubular-filiform with denticulate apex. Cypselae 2 to 8(10)-ribbed; pappus persistent, multiseriate, acrescent or not.

Southeastern South America open vegetations; two sections and 13 species.

Baccharis subgen. Oblongifoliae (DC.) G.Heiden, Phytotaxa 289(3): 289, 2016. ( $\equiv$ Baccharis sect. Oblongifoliae DC., Prodr. 5: 4I6. 1836. Type (designated by Cuatrecasas in Revista Acad. Colomb. Ci. Exact. 13: 66. 1967): Molina oblongifolia Ruiz \& Pav. (三 Baccharis oblongifolia (Ruiz \& Pav.) Pers.).

Trees, shrubs, scandent shrubs, or subshrubs. Indument tufted, uniseriate, pedestal and/or biseriate glandular trichomes. Stems apterous. 
CAPITULA

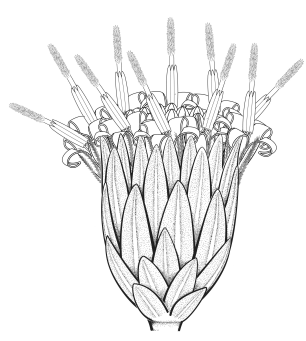

Homogamous

Staminate florets

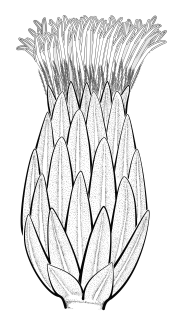

Homogamous

Pistillate florets

with filiform corollas

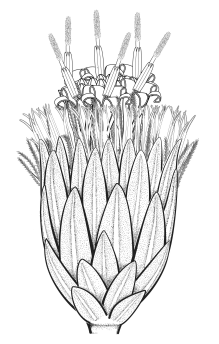

Heterogamous

Outer pistillate florets inner monoclinous florets with tubulose corollas
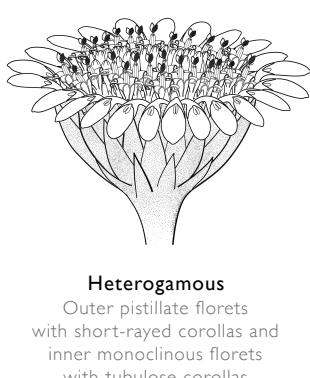

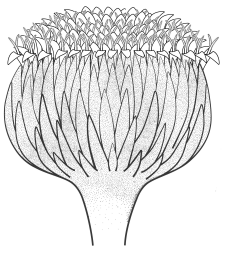

Homogamous Pistillate florets with short-rayed corollas

\section{COROLLAS OF STAMINATE FLORETS}

COROLLAS OF PISTILLATE FLORETS
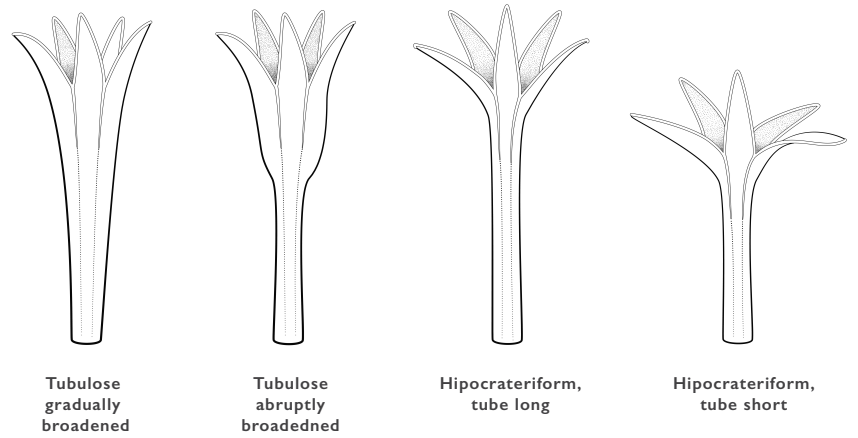

Hipocrateriform,
tube long

Hipocrateriform,
tube short broadedned

STYLES

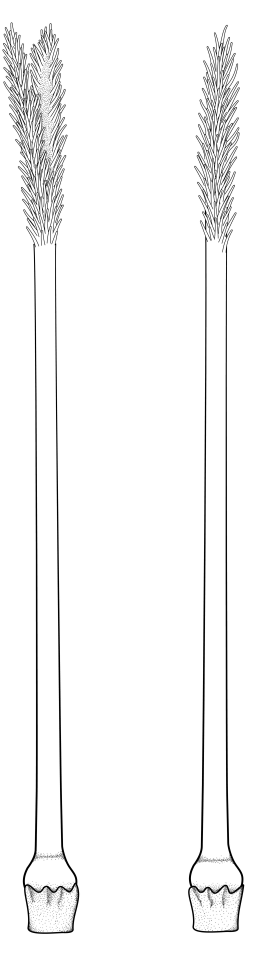

Apex linear-oblong

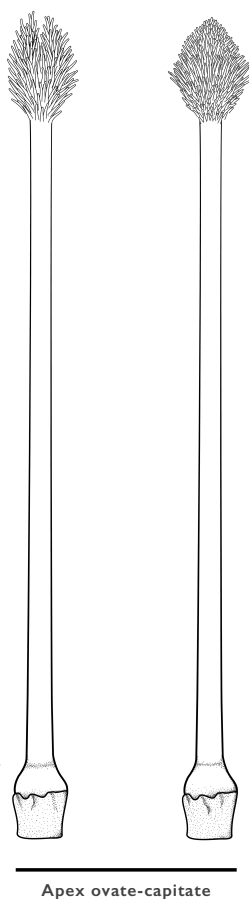

Pistilodium of monoclinous florets

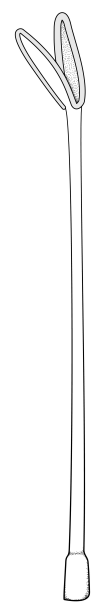

Style of pistillate florets

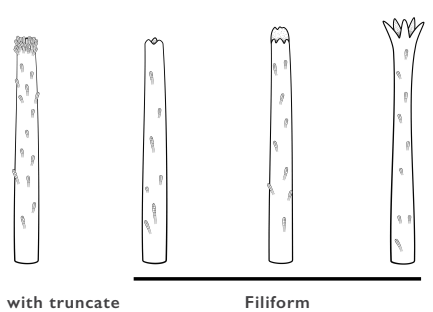

Filiform with truncate apex with subapical wreath of trichome

with denticulate apex

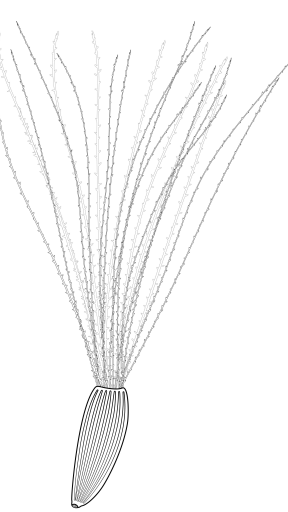

Tapering \& scabrid pappus elements
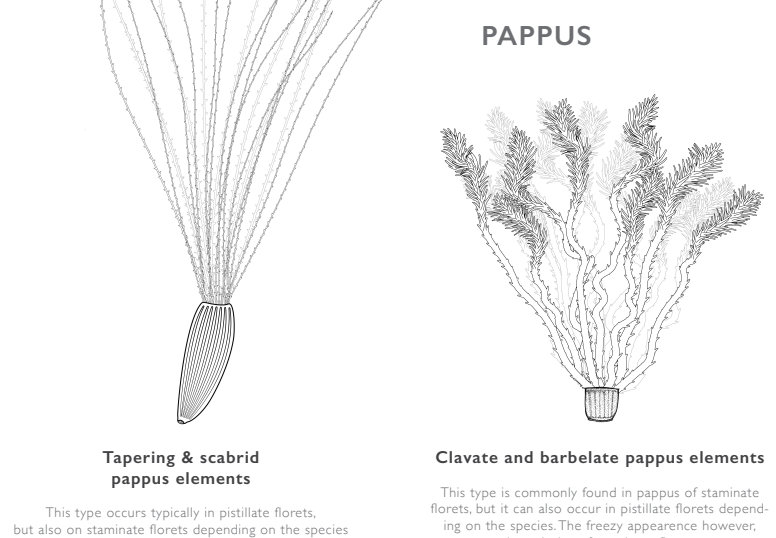

CYPSELAE
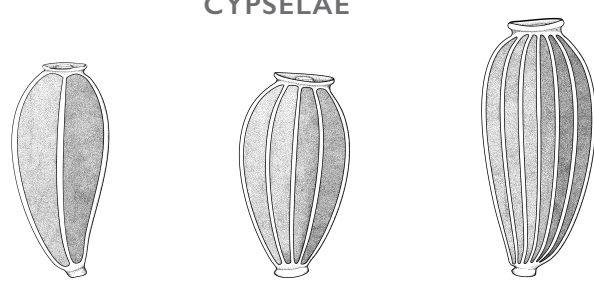

$<5$ ribs
$>8$ ribs Style branches arms range from free to totally fused an

Figure II. Some morphological reproductive characters important for the infrageneric taxonomy and useful in the identification of Baccharis. 


\section{CLASSIFICATION OF BACCHARIS}

INFRAGENERIC DIVERSITY PLOTTED ON AN UNROOTED PHYLOGENY

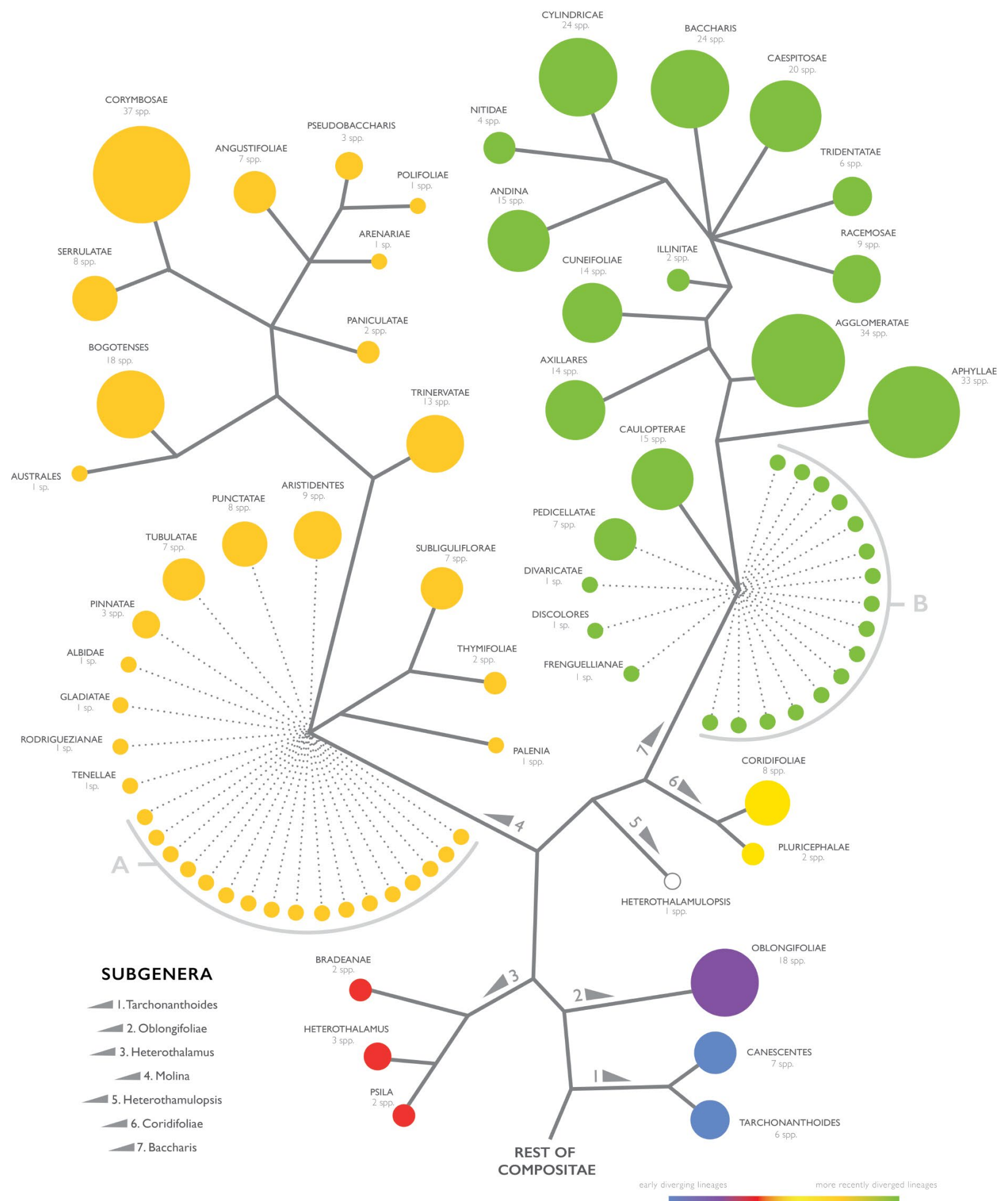

Figure 12. Unrooted phylogeny of Baccharis (adapted from Heiden et al. 2019). Circle size is indicative of species number. Dotted lines indicate sections or species with uncertain or undetermined relationships (placed within subgenera based on morphology but with pending subgeneric relationships corroborated by molecular data.). A. Species belonging to Baccharis subgen. Molina but not formally assigned to sections. B. Species belonging to Baccharis subgen. Baccharis but not formally assigned to sections. 

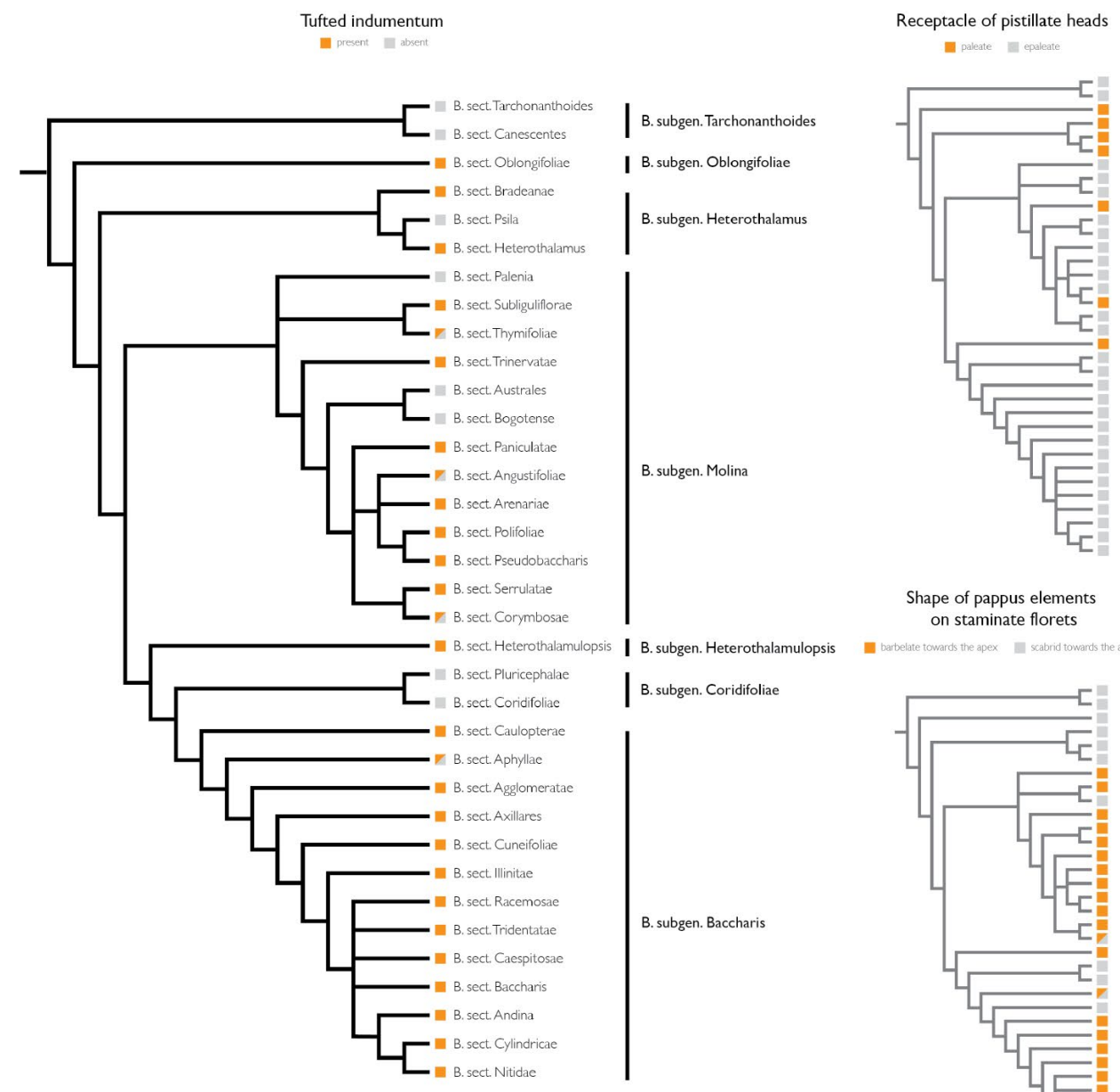

Shape of style apex

on staminate florets

al capitite ovate In linear-oblong
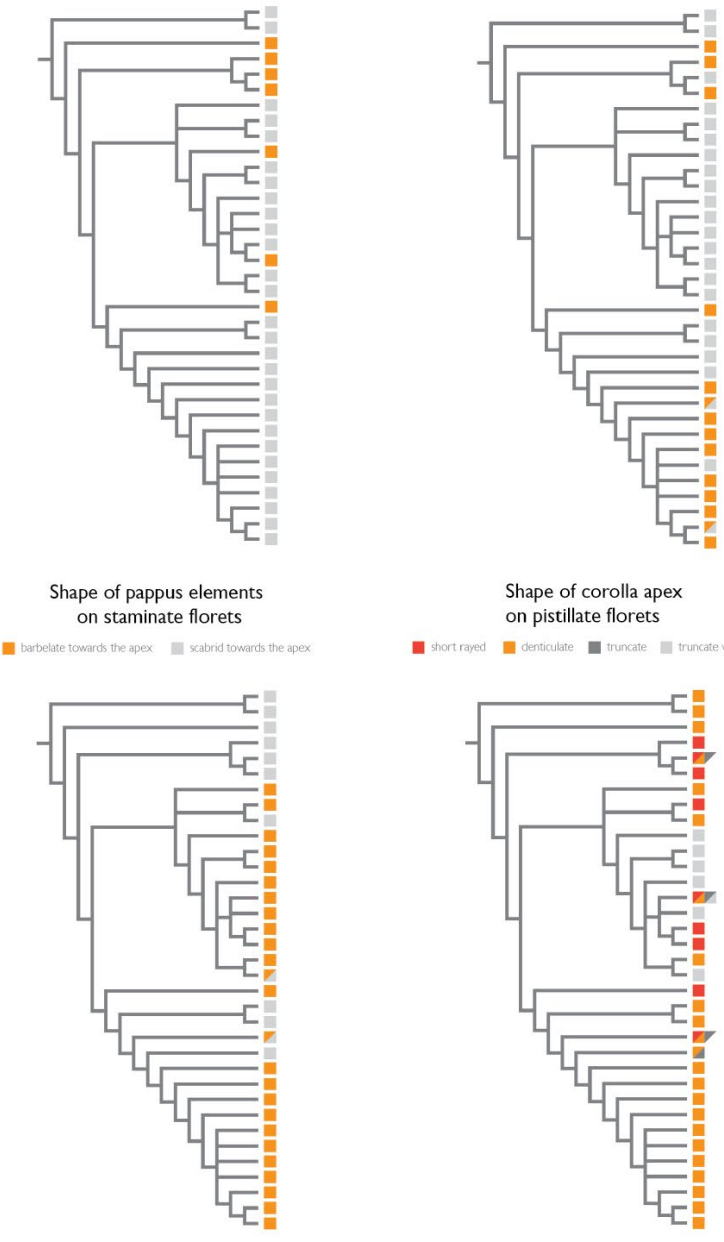

Shape of corolla apex on pistillate florets

In short rayed in denticulate
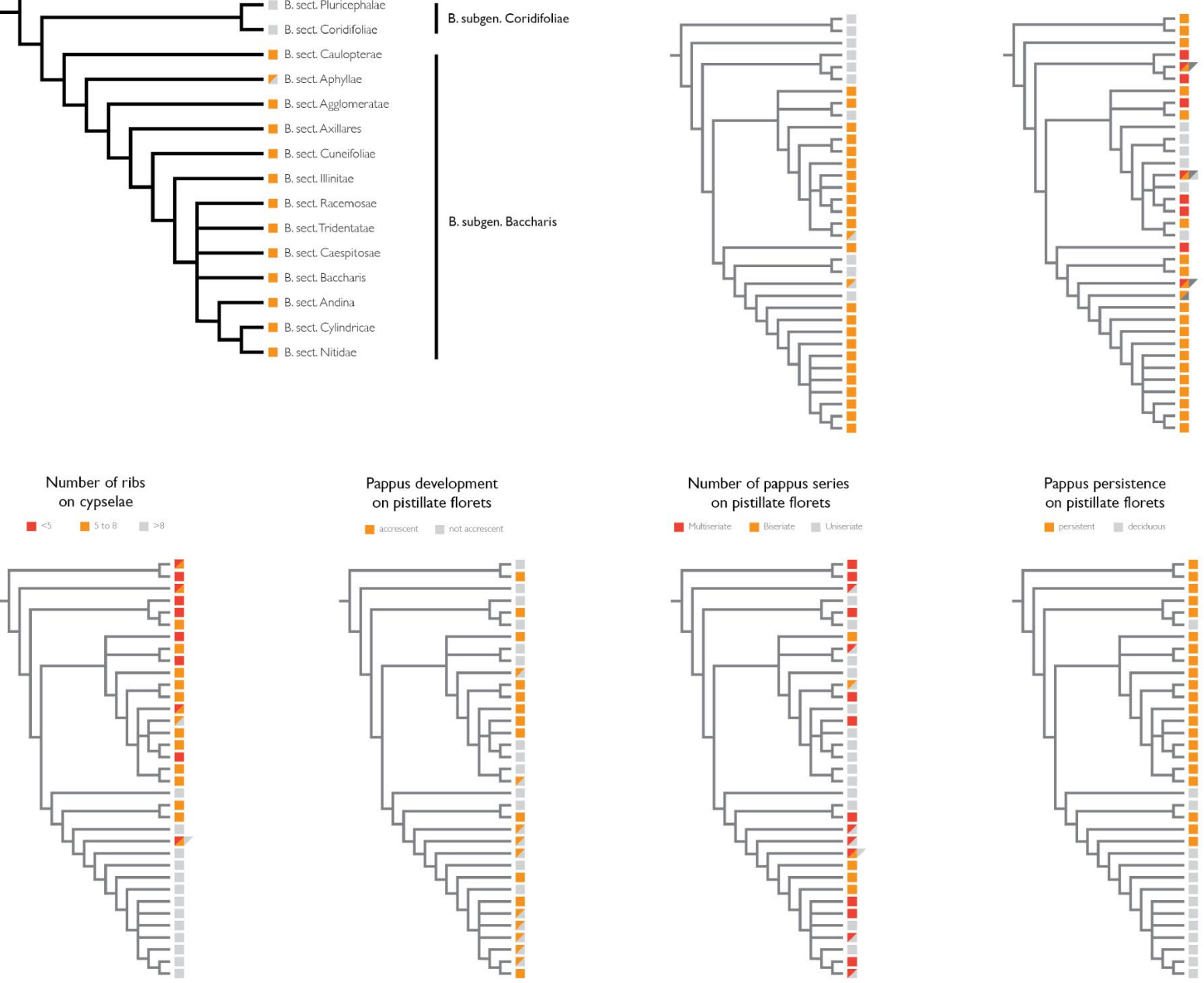

Pappus persistence on pistillate florets
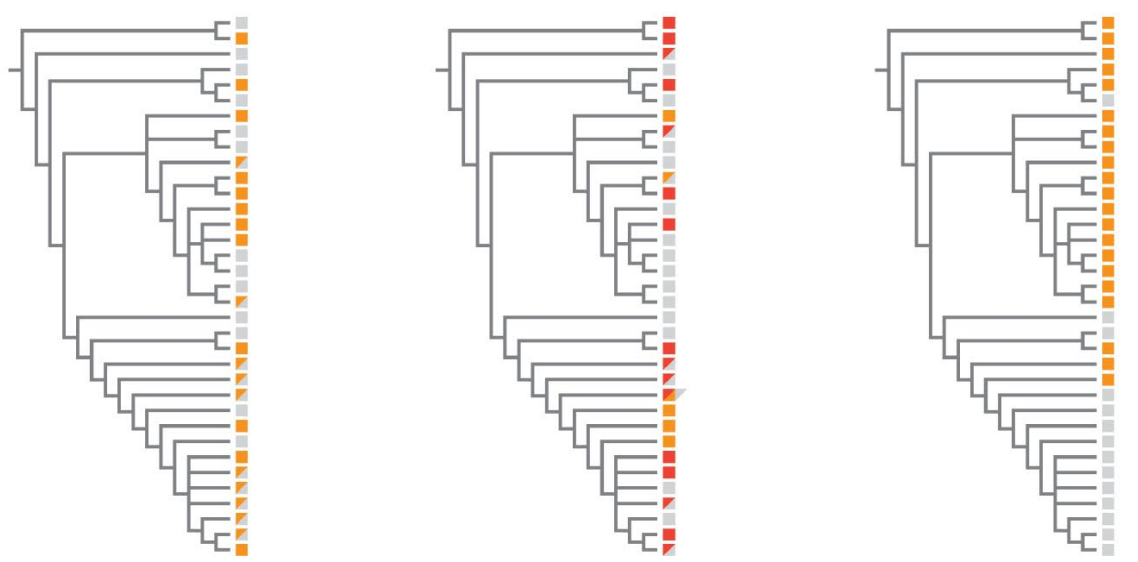

Figure I 3. Selected morphological characters useful for identification of Baccharis infrageneric groups. The characters are ploted in a summarized phylogeny based on Heiden et al. (2019). 
Table I. Data matrix of morphological characters useful in the identification of Baccharis infrageneric groups. Names in bold face indicate taxa included in the phylogeny by Heiden et al. (2019). For characters used and their states see Table 2.

Subgenera

Sections

B. sect. Tarchonanthoides

B. subgen. Tarchonanthoides

B. subgen. Oblongifolieae

B. subgen. Heterothalamus

B. sect. Canescentes

B. sect. Oblongifolieae

B. sect. Bradeanae

B. sect. Heterothalamus
B. sect. Psila

B. sect. Palenia

B. sect. Subliguliflorae

B. sect. Thymifoliae

B. sect. Trinervatae

B. sect. Australes

B. sect. Bogotenses

B. sect. Paniculatae

B. sect. Arenariae

B. sect. Polifoliae

B. sect. Pseudobaccharis

B. subgen. Molina

B. subgen. Baccharis
B. sect. Angustifoliae

B. sect. Serrulatae

B. sect. Corymbosae

B. sect. Albidae

B. sect. Aristidentes

B. sect. Gladiatae

B. sect. Pinnatae

B. sect. Punctatae

B. sect. Rodriguezianae

B. sect. Tenellae

B. sect.Tubulatae

B. subgen. Heterothalamulopsis

B. subgen. Coridifoliae

B. sect. Heterothalamulopsis

B. sect. Pluricephalae

B. sect. Coridifoliae

B. sect. Caulopterae

B. sect. Aphyllae

B. sect. Agglomeratae

B. sect. Axillares

B. sect. Cuneifoliae

B. sect. Illinitae

B. sect. Racemosae

B. sect. Tridentatae

B. sect. Caespitosae

B. sect. Baccharis

B. sect. Andina

B. sect. Cylindricae

B. sect. Nitidae

B. sect. Discolores

B. sect. Divaricatae

B. sect. Frenguellianae

B. sect. Pedicellatae

\section{Characters} \begin{tabular}{l|l|l|l|l|l|l|l|l|l|l|l}
\hline I & 2 & 3 & 4 & 5 & 6 & 7 & 8 & 9 & 10 & 11 & 12 \\
\hline
\end{tabular}

\begin{tabular}{|c|c|c|c|c|c|c|c|c|c|c|}
\hline V & $\square$ & $\square$ & $\square$ & $\square$ & $\square$ & $\square$ & $\bar{\square}$ & $\square$ & 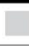 & $\bar{Z}$ \\
\hline$\square$ & $\square$ & $\square$ & $\square$ & 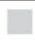 & $\square$ & $\square$ & $\square$ & $\square$ & $\square$ & $\square$ \\
\hline 14 & 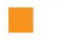 & $\square$ & $\square$ & $\square$ & $\square$ & $\square$ & $\nabla$ & 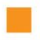 & 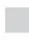 & $\square$ \\
\hline$\square$ & $\triangle$ & $\square$ & $\square$ & 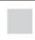 & $\square$ & $\square$ & 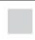 & $\square$ & 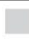 & $\square$ \\
\hline$\square$ & $\square$ & $\square$ & $\square$ & $\square$ & $\square$ & $\square$ & 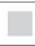 & $\square$ & - & $\square$ \\
\hline$\square$ & $\square$ & $\square$ & $\square$ & $\square$ & $\nabla$ & $\square$ & $\square$ & $\square$ & L & $\square$ \\
\hline$\square$ & $\square$ & $\square$ & $\square$ & $\square$ & $\square$ & $\square$ & $\square$ & $\square$ & 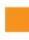 & $\square$ \\
\hline$\square$ & $\square$ & $\square$ & $\square$ & $\square$ & $\square$ & $\square$ & $\Gamma$ & $\square$ & 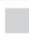 & $\square$ \\
\hline $\bar{Z}$ & $\square$ & $\square$ & $\square$ & 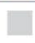 & $\square$ & $\square$ & 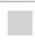 & $\square$ & 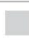 & $\square$ \\
\hline 7 & $\square$ & $\square$ & $\square$ & $\square$ & $\square$ & $\square$ & 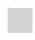 & $\square$ & $\Gamma$ & $\square$ \\
\hline$\square$ & $\square$ & $\square$ & $\square$ & $\square$ & $\square$ & $\square$ & $\nabla$ & $\square$ & $\square$ & $\square$ \\
\hline$\nabla$ & $\square$ & $\square$ & $\square$ & $\square$ & $\square$ & $\square$ & $\square$ & $\square$ & $\square$ & $\square$ \\
\hline$\square$ & $\square$ & $\square$ & $\square$ & $\square$ & 口 & $\square$ & $\square$ & $\square$ & 口 & $\nabla$ \\
\hline$\square$ & $\square$ & $\square$ & $\square$ & $\square$ & D & $\square$ & $\square$ & $\square$ & L & $\square$ \\
\hline$\square$ & $\square$ & $\square$ & $\square$ & $\square$ & $\square$ & 口 & 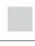 & $\square$ & 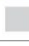 & - \\
\hline$\square$ & $\square$ & $\square$ & $\square$ & $\square$ & $\square$ & $\square$ & 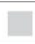 & $\square$ & 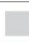 & $\square$ \\
\hline$\nabla$ & $\square$ & $\square$ & $\square$ & $\square$ & $\nabla$ & $\square$ & $\square$ & $\square$ & $\square$ & $\bar{\nabla}$ \\
\hline$\square$ & $\square$ & $\square$ & $\square$ & $\square$ & $\square$ & $\square$ & 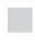 & $\square$ & 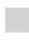 & $\square$ \\
\hline $14 V$ & $\nabla$ & $\square$ & $\square$ & $\Gamma$ & $\square$ & $\square$ & 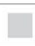 & $\square$ & $\Gamma$ & - \\
\hline 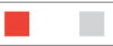 & $\square$ & $\square$ & $\square$ & $\square$ & $\square$ & $\square$ & 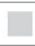 & $\square$ & $\square$ & $\square$ \\
\hline$\square$ & Z & $\square$ & $\square$ & $\square$ & $\square$ & $\square$ & $\square$ & $\square$ & $\square$ & $\square$ \\
\hline$\square$ & $\square$ & $\square$ & $\square$ & $\square$ & $\square$ & $\square$ & $\square$ & $\square$ & 口 & - \\
\hline$\square$ & $\square$ & $\square$ & $\square$ & $\square$ & $\square$ & $\square$ & D & $\square$ & 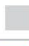 & $\square$ \\
\hline$\square$ & $\square$ & $\square$ & $\square$ & $\square$ & $\square$ & $\square$ & $\square$ & $\square$ & $\square$ & $\square$ \\
\hline$\square$ & $\square$ & $\square$ & $\square$ & L & $\square$ & $\square$ & L & $\square$ & 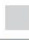 & $\square$ \\
\hline$\square$ & $\square$ & $\square$ & $\square$ & 口 & $\square$ & $\square$ & $\square$ & $\square$ & 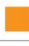 & LE \\
\hline$\square$ & E & 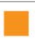 & $\square$ & $\square$ & $\nabla$ & $\square$ & $\square$ & & & 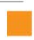 \\
\hline
\end{tabular}

r


Table2. Characters and character states useful in identification of Baccharis.

\begin{tabular}{|c|c|}
\hline Characters & Character's state \\
\hline Habit I & Shrubs $\square$ Subshrubs $\square$ Trees $\square$ Scandent shrubs $\mathbf{D}$ Herbs $\mathbf{a}$ Rhizomatous shrubs \\
\hline Tufted indumentum 2 & $\square$ Present $\square$ Absent \\
\hline Capitulum structure 3 & Halimifolia type $\square$ Aliena type $\square$ Monoica type $\square$ Punctulata type $\square$ Breviseta type $\square$ Pohlii type \\
\hline Staminate capitula 4 & Discoid Heterogamous, marginal corollas short-rayed $\quad$ Heterogamous, marginal corollas long-rayed \\
\hline Shape of style apex on staminate florets 5 & Capitate-ovate $\square$ Linear-oblong \\
\hline Shape of pappus elements on staminate florets 6 & Barbelate towards the apex Scabrid towards the apex \\
\hline Shape of corolla apex on pistillate florets 7 & - Short rayed Denticulate $\quad$ Truncate $\quad$ Truncate apex with subapical wreath of trichomes \\
\hline Receptacle of pistillate capitula 8 & — Paleate Epaleate \\
\hline Number of pappus series on pistillate florets 9 & Multiseriate Biseriate $\square$ Uniseriate \\
\hline Pappus persistence on pistillate florets 10 & Dersistent Deciduous \\
\hline Pappus development on pistillate florets II & Accrescent $\square$ Not accrescent \\
\hline Number of ribs on cypselae 12 & $\square<5 \square 5$ to $8 \square>8$ \\
\hline
\end{tabular}

Indument re of indument identification. In this case trichomes are densely packed together covering the whole surface of the fruit, ribs included.

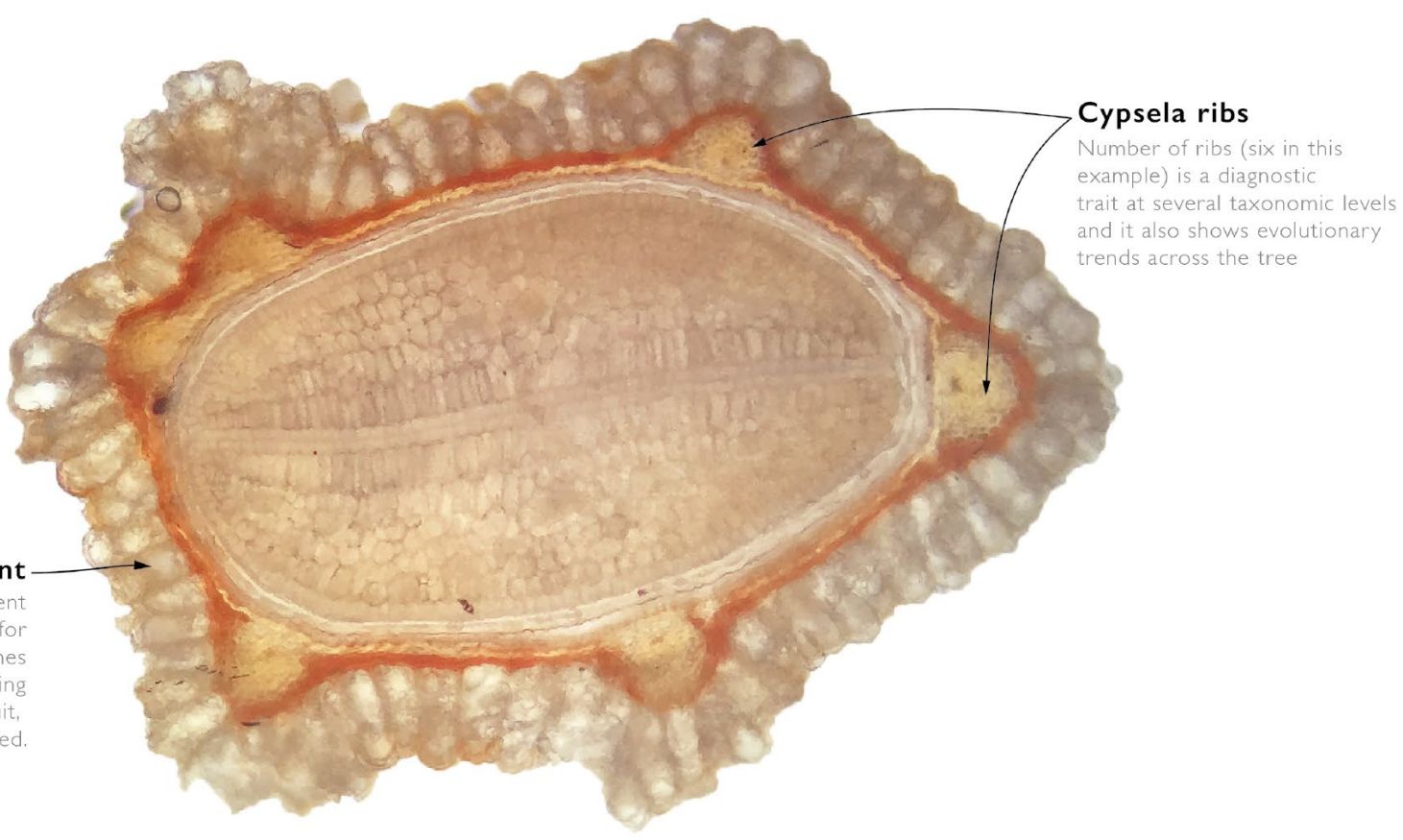

Figure 14. Cross section of the cypsela of Baccharis patens Baker showing the presence of six ribs. Number of ribs is a character readily determined by means of producing a bare hand simple section like this. Notice copious indument covering the whole surface. Photo: M. Bonifacino. 
Leaves developed. Capitula homogamous, structure and arrangement of Halimifolia type. Receptacle of pistillate capitula paleate. Staminate florets with pappus elements clavate and scabrid towards the apex, pistillodium apex capitate. Pistillate florets with corollas filiform with denticulate apex. Cypselae 3 to 7-ribbed; pappus persistent, multiseriate, not acrescent.

High slopes and mountain summits across tropical and subtropical South America; one section and 18 species.

Baccharis subgen. Heterothalamus (Less.) G. Heiden, Phytotaxa 289(3): 288, 2016. ( $\equiv$ Heterothalamus Less. in Linnaea 5: 145. I 830. Type: Marshallia aliena Spreng. (三 Baccharis aliena (Spreng.) Joch.Müll.).

Trees, shrubs, and rhizomatous subshrubs. Indument tufted or not, pedestal trichomes or glabrous. Stems apterous. Leaves developed on aerial branches or sometimes reduced to scales in underground rhizomes. Capitula homogamous or heterogamous, structure and arrangement of Halimifolia or Aliena type. Receptacle of pistillate capitula paleate. Staminate florets with pappus elements linear and scabrid towards the apex, pistillodium apex capitate. Pistillate florets with corollas tubular and with short-rayed apex, or filiform with denticulate or truncate apex. Cypselae 3 to 5(6)-ribbed; pappus deciduous or persistent, uniseriate or multiseriate, accrescent or not.

Mountains, rocky outcrops, sandy or salty soils along the Andes and the Eastern South American mountainous and hilly ranges; three sections and seven species.

Baccharis subgen. Molina (Pers.) Heering, Schriften Naturwiss. Vereins Schleswig-Holstein 13: 40, 1904. (三 Molina Ruiz \& Pav., Prodr. Fl. Peruv.: III, t. 24. 1794, non Molina Cav. 1790 (Malpighiaceae), nec Molina Gay 185I,Äìl852 (Euphorbiaceae) ミ Baccharis [unranked "group"] Molina Pers., Syn. PI. 2: 424. 1807. Type (designated by Cuatrecasas in Revista Acad. Colomb. Ci. Exact. 13: 87. 1967): Molina latifolia Ruiz \& Pav. (三 Baccharis latifolia (Ruiz \& Pav.) Pers.).

Trees, shrubs, scandent shrubs, subshrubs, rhizomatous subshrubs or herbs. Indument tufted or not, flagellate, clavate, filiform, pedestal or curved uniseriate and/orbiseriate glandulartrichomes. Stems apterous. Leaves developed or reduced to scales. Capitula homogamous or heterogamous, structure and arrangement mostly of Halimifolia type, rarely Breviseta, Monoica, Pohlii and Punctulata types. Receptacle of pistillate capitula generally epaleate, sometimes paleate. Staminate florets with pappus elements mostly linear and barbellate towards the apex, rarely scabrid towards the apex, pistillodium apex linear-oblong. Pistillate florets with filiform corollas and short-rayed, denticulate or truncate apex, the later with or without a subapical wreath of trichomes. Cypselae 5 to 8-ribbed; pappus mostly persistent, rarely deciduous, uniseriate, biseriate or multiseriate, generally accrescent, sometimes not.

Widespread in a plethora of habitats from deserts to rainforests, from seashores to high summits around 5,000 $\mathrm{m}$ asl, from the southwestern USA to southern South America, including oceanic islands; 21 sections and 150 species.

Baccharis subgen. Heterothalamulopsis (Deble, A.S.Oliveira \& Marchiori) G.Heiden, Phytotaxa 289(3): 287, 2016. ( $\equiv$ Heterothalamulopsis Deble, A.S.Oliveira \& Marchiori in Ci. Florest. I 4(I): I 2004. Type: Heterothalamulopsis wagenitzii (F.H.Hellw.) Deble,A.S.Oliveira\&Marchiori (三 Baccharis wagenitzii (F.H.Hellw.) Joch.Müll.).

Shrubs or subshrubs. Indument tufted. Stems apterous. Leaves developed. Capitula homogamous, structure and arrangement of Halimifolia type. Receptacle of pistillate capitula paleate. Staminate florets with pappus elements clavate and barbellate towards the apex, pistillodium apex capitate. Pistillate florets with corollas tubular and shortrayed apex. Cypselae 10-ribbed; pappus deciduous, uniseriate, not accrescent.

Endemic to the cloud forests on the edges of basaltic cliffs and canyons of southern Brazil; one section and one species.

Baccharis subgen. Coridifoliae (Giuliano) G. Heiden, Phytotaxa 289(3): 286 (2016). E Baccharis sect. Coridifoliae Giuliano in Ann. Missouri Bot. Gard. 98(3): 339. 201 I. Type: Baccharis coridifolia DC.

Shrubs or subshrubs. Indument not tufted, mostly filiform trichomes, sometimes trichomes paired 


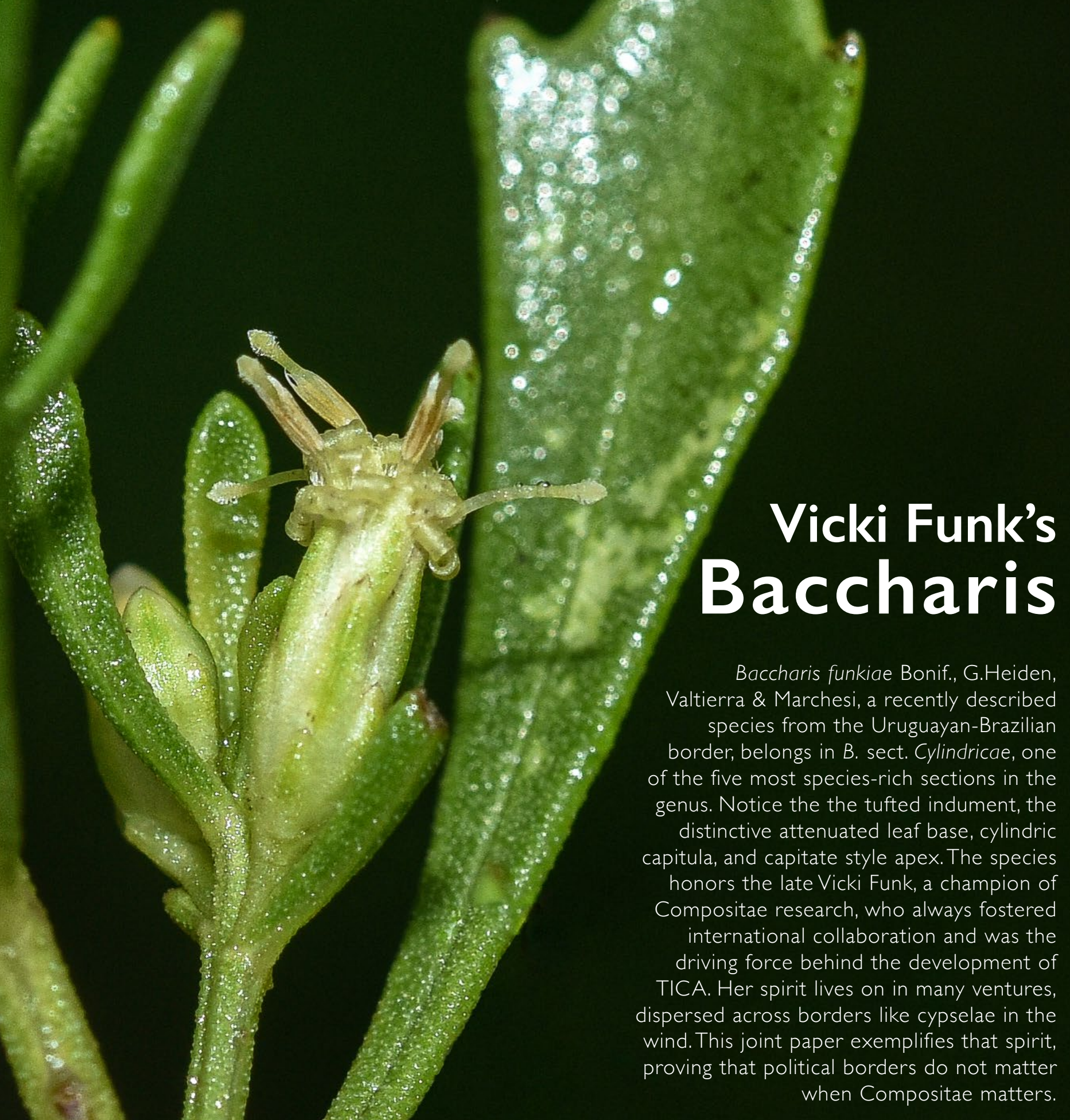


or uniseriate, pedestal and/or biseriate glandular trichomes. Stems apterous. Leaves developed. Capitula homogamous, structure and arrangement of Baccharis type. Receptacle of pistillate capitula epaleate. Staminate florets with pappus elements llinear and scabrid towards the apex, pistillodium apex linear-oblong. Pistillate florets with corollas tubular-filiform with denticulate apex. Cypselae 5 to 8-ribbed; pappus deciduous or persistent, uniseriate or multiseriate, acrescent or not.

Grasslands and savannas from Bolivia and central Brazil, south to central Argentina across Paraguay and Uruguay; two sections and 10 species.

\section{Baccharis subgen. Baccharis.}

Trees, shrubs, scandent shrubs, subshrubs or rhizomatous subshrubs. Indument mostly tufted, rarely not tufted, always with biseriate glandular trichomes, uniseriate flagellate, clavate, filiform or bifurcate trichomes. Stems apterous, striated or alate due leaf basis decurrence. Leaves developed or reduced to scales. Capitula homogamous, rarely heterogamous, structure and arrangement mostly of Halimifolia type, rarely Breviseta or Punctulata types. Receptacle of pistillate capitula epaleate. Staminate florets with pappus elements mostly clavate and barbellate towards the apex, sometimes scabrid towards the apex, pistillodium apex, mostly capitate, sometimes linear-oblong. Pistillate florets with corollas filiform with denticulate apex, rarely short-rayed or truncate. Cypselae ( 3 to 7) 8 to 12(20)-ribbed; pappus mostly deciduous, sometimes persistent, uniseriate, biseriate or multiseriate, acrescent or not.

Widespread in a plethora of habitats from deserts to rainforests, from seashores to high summits around 5,000 $\mathrm{m}$ a.s.l. from the Northwestern USA and Southeastern Canada to Southern South America, including oceanic islands; 17 sections and 24I species.

\section{ACKNOWLEDGEMENTS}

$\mathrm{GH}$ and $\mathrm{MB}$ thank the Linnean Society for the granted permission to use the image of Baccharis type, and Valeria Romano for her valuable contributions with the text. GH thanks the Systematics Research Fund
2015/16 and LinnéSys 2020/202 I by the research awards provided and CNPq (3/4590/2020-0) for the research productivity fellowship. MB thanks Agencia Nacional de Investigación e Innovación through grant FCE-20I4-104963 and Facultad de Agronomía \& Facultad de Ciencias.

\section{LITERATURE CITED}

Boldt, P.E. 1989. Baccharis (Asteraceae), a review of its taxonomy, phytochemistry, ecology, economic status, natural enemies and the potential for its biological control in the United States. Texas: College Station.

Heiden, G., Antonelli, A. \& Pirani, J.R. 2019. A novel phylogenetic infrageneric classification of Baccharis (Compositae: Astereae), a highly diversified American genus. Taxon 68: |048-108|.

Jarvis, B.B., Çömezoglu, S.N., Rao, M.M., Pena, N.B. \& F.E. Boettner. 1987. Isolation of macrocyclic trichothecenes from a large scale extract of Baccharis megapotamica. J Org. Chem. 52: 45-56

Jarvis, B.B., Mokhtari-Rejali, N., Schenkel, E.P., Barros C.S.L. \& Matzenbacher, N.I. 1991. Trichothecene mycotoxins from Brazilian Baccharis species. Phytochemistry 30: 789-797

Müller, J. 2006. Systematics of Baccharis (CompositaeAstereae) in Bolivia, including an overview of the genus. Systematic Botany Monographs 76: I-34I.

Quatrocchi, H. 1999. CRC World Dictionary of Plant Names: Common Names, Scientific Names, Eponyms, Synonyms, and Etymology. 4 vols. Boca Raton: CRC Press.

Thompson, A.E., Lee, C.W. \& Gass, R.E. 1995. Development of hybrid Baccharis plants for desert landscaping. HortScience 30: | 357-1362

Volkens, G. 1890. Ueber Pflanzen mit lackiert Blättern. Berichte der Deutschen Botanischen Gesellschaft 8: | 20-|40, t.VIII-IX. 